Contents list available at IJRED website

Int. Journal of Renewable Energy Development (IJRED)

Journal homepage: https://ijred.undip.ac.id

\title{
Performance and Emission Characteristics of Diesel Engine Using Ether Additives: A Review
}

\author{
Bao Quoc Doan ${ }^{1}$, Xuan Phuong Nguyen², Van Viet Pham ${ }^{2, *}$, Thi Minh Hao Dong², \\ Minh Tuan Pham ${ }^{4}$, Tan Sang Le,"* \\ ${ }^{1}$ Faculty of Mechanical Engineering (FME), Industrial University of Ho Chi Minh City (IUH), Ho Chi Minh City, Vietnam \\ ${ }^{2}$ PATET Research Group, Ho Chi Minh City University of Transport, Ho Chi Minh City, Vietnam \\ ${ }^{3}$ Institute of Maritime, Ho Chi Minh City University of Transport, Ho Chi Minh City, Vietnam \\ ${ }^{4}$ School of Transportation Engineering, Hanoi University of Science and Technology, Hanoi, Vietnam
}

${ }^{5}$ Institute of Engineering, HUTECH University, Ho Chi Minh city, Vietnam

\begin{abstract}
Pressure on alternative fuels and strict environmental regulations are driving a strategic shift in the efficient use of renewable biofuels. One of the promising biofuel candidates recently interested by scholars is a biological or organic additive that is added into diesel or biodiesel fuel to improve engine performance and reduce pollutant emissions. With efforts to improve efficiency and combustion quality in cylinders, combustion characteristics, flame structure and emission formation mechanism in compression ignition (CI) engines using blended fuel with organic additives have been studied on the effect of additive properties on the combustion behaviour. In this review, the physicochemical properties of typical organic additives such as ethers compounds and their effects on engine performance and emission characteristics have been discussed and evaluated based on conclusions of recent relevant literature. The results of the analysis revealed the prospect of using ether additives to improve combustion in cylinders and reduce pollutant emissions from CI engines. Obviously, the presence of higher oxygen content, lower viscosity and density, and higher cetane number resulted in a positive change in the combustion dynamics as well as a chain of mechanisms for the formation of pollutant precursors in the cylinder. Therefore, ether additives have a significant contribution to the sustainable energy strategy of the transportation sector in the next period when internal combustion engines still dominate in the competition for energy system choices equipped on vehicles.
\end{abstract}

Keywords: Ether additives; engine performance; emission characteristics; biodiesel; diesel engine.

Article History: Received: $8^{\text {th }}$ Oct 2021; Revised:16 th Nov 2021; Accepted: $2^{\text {th }}$ Nov 2021; Available online: $27^{\text {th }}$ Nov 2021

How to Cite This Article: Doan, B.Q., Nguyen, X.P., Pham, V.V., Dong, T.M.H., Pham, M.T., and Le, T.S. (2022) Performance and emission characteristics of diesel engine using ether additives: A review. International Journal of Renewable Energy Development, 11(1), 255-274 https://doi.org/10.14710/ijred.2022.42522

\section{Introduction}

Global warming, air pollution and the depletion of fossil fuels are raising serious concerns about the impact of the use of vehicles with internal combustion engines (Keleş, 2011)(Höök and Tang, 2013). However, reality shows that the current demand for internal combustion engines is still very large (Chau et al. 2020). Over $90 \%$ of the power sources in transport vehicles are spark-ignition engines and compression ignition engines (Leach et al., 2020)(Atarod et al., 2021). Indeed, diesel engines are still the favourite choice for transport vehicles because of their large power, high thermal efficiency, stability and reliability (Thambiyapillai and Ramanujam, 2021). However, diesel fuel contains mainly aliphatic hydrocarbons with boiling points between 130 and $370^{\circ} \mathrm{C}$. As a result, emissions from diesel engines contain pollutants such as particulate emissions (PM) (Nayak et al., 2020)(Ruina et al., 2021), carbon monoxide (CO) (Ölçer et al., 2021a)(Sivamurugan and Devarajan, 2021) and oxides of nitrogen (NOx) (Le et al., 2021)(Korczewski, 2021). These pollutants can cause extreme environmental phenomena and global climate change (Nižetić et al., 2020)(Nayak et al., 2021). Furthermore, the applications of diesel are being tightened by strict regulations on fossil fuel use, pollution emissions, and greenhouse gas emissions engines (Viet and Tuan, 2018)(Balasubramanian et al., 2021c)(Bui et al., 2021). The elimination of the internal combustion engine is a long-term prospect in the future (Nguyen et al., 2020)(Vo et al., 2020). Nonetheless, in the short- term, there needs to be a flexible combination of effective solutions including improving engine characteristics, reducing emissions actively and passively (Vinayagam et al., 2021) (Balasubramanian et al., 2021a). Currently, researchers are focusing on three main solutions (Figure 1): the first is to improve the combustion process (Cao et al., 2020) or optimize the engine design to meet the dual goals of

\footnotetext{
* Corresponding author: Van Viet Pham (viet.pham@ut.edu.vn); Tan Sang Le (lt.sang@hutech.edu.vn)
} 
performance and environmental protection (Tran et al. 2020); the second is the use of secondary interventions through emission treatment technologies (Hoang, 2018)(Chen et al., 2021b)(Trung et al., 2021); third is the search for sustainable and renewable alternative fuels such as hydrogen (Bui et al., 2021) and various biofuel types such as furan-based fuel (Engel et al., 2021)(Ölçer et al., 2021b), biodiesel (Anh, 2018), alcohol (Zeńczak and Krystosik-Gromadzińska, 2020), vegetable oils (Tabatabaei et al., 2021). In addition, sustainable energy conversion, recovery and storage solutions include energy storage in flywheels (Nguyen and Hoang, 2020), waste heat recovery (Yondri et al., 2021)(Anh, 2018), microbial fuel cells (Nižetić et al., 2022), etc. could be potential solutions. The application of advanced engine generations or advanced emission treatment technologies may encounter economic barriers and initial investment costs (Khan et al., 2015). Meanwhile, the use of renewable biodiesel fuels is attracting a lot of attention from academia to move towards reducing dependence on fossil fuels as well as proactive control of emission sources from the engine. Moreover, biodiesel is environmentally friendly, so it has been seen as a great alternative to traditional fuels. The use of biodiesel for CI engines requires minor modifications to traditional engines. Another advantage is the relatively wide and easy access to renewable fuels (Mukherjee et al., 2020). In the trend of shifting biofuel production to meet global strategies for decarbonization, biofuel production from biomass is attracting much attention (Huynh et al., 2021). With the aid of advanced technologies in biomass pretreatment (Chen et al., 2021a) and conversion (Chong et al., 2021), biorefineries have been able to produce many high valueadded products with improved efficiency such as bioalcohol (Al-Tawaha et al., 2019), biodiesel, syngas, hydrogen (Arslan and Kahraman, 2021) and organic additives (Uyaroğlu et al., 2021)(Nayak et al., 2022).

Along with the outstanding advantages, biodiesel fuel has inherent disadvantages such as high viscosity, higher density and lower volatile characteristics compared to diesel, leading to undesirable effects on combustion behaviour (Lawan et al., 2019)(Nayak et al., 2017)(Le et al., 2019), combustion chamber deposit formation (Le and Hoang, 2019)(Pham and Hoang, 2019a), lubrication oil degradation (Pham and Hoang, 2019b). Furthermore, the energy density of biodiesel fuels is lower than that of diesel fuel, so the specific fuel consumption may be higher (Tham et al., 2019)(Hadiyanto et al., 2020). In addition, the cetane number of biodiesel fuels has been reported to be lower than pure diesel fuel. That means finding an additive or chemical that can be mixed in small proportions with diesel or biodiesel fuels to give beneficial properties to the blended fuels and boost biofuel efficiency (Sezer, 2018). Current studies often classify diesel additives into two categories including organic and inorganic additives. However, organic additives are more common in biodiesel or diesel fuel applications for CI engines. The groups of organic additives can be mentioned as alcohol, ether, aromatic, aliphatic, nitro paraffin, ester. Studies in recent decades have focused a lot on evaluating the effects of alcohol additives in diesel fuel on engine characteristics, combustion characteristics and emissions (Pranesh et al., 2015).

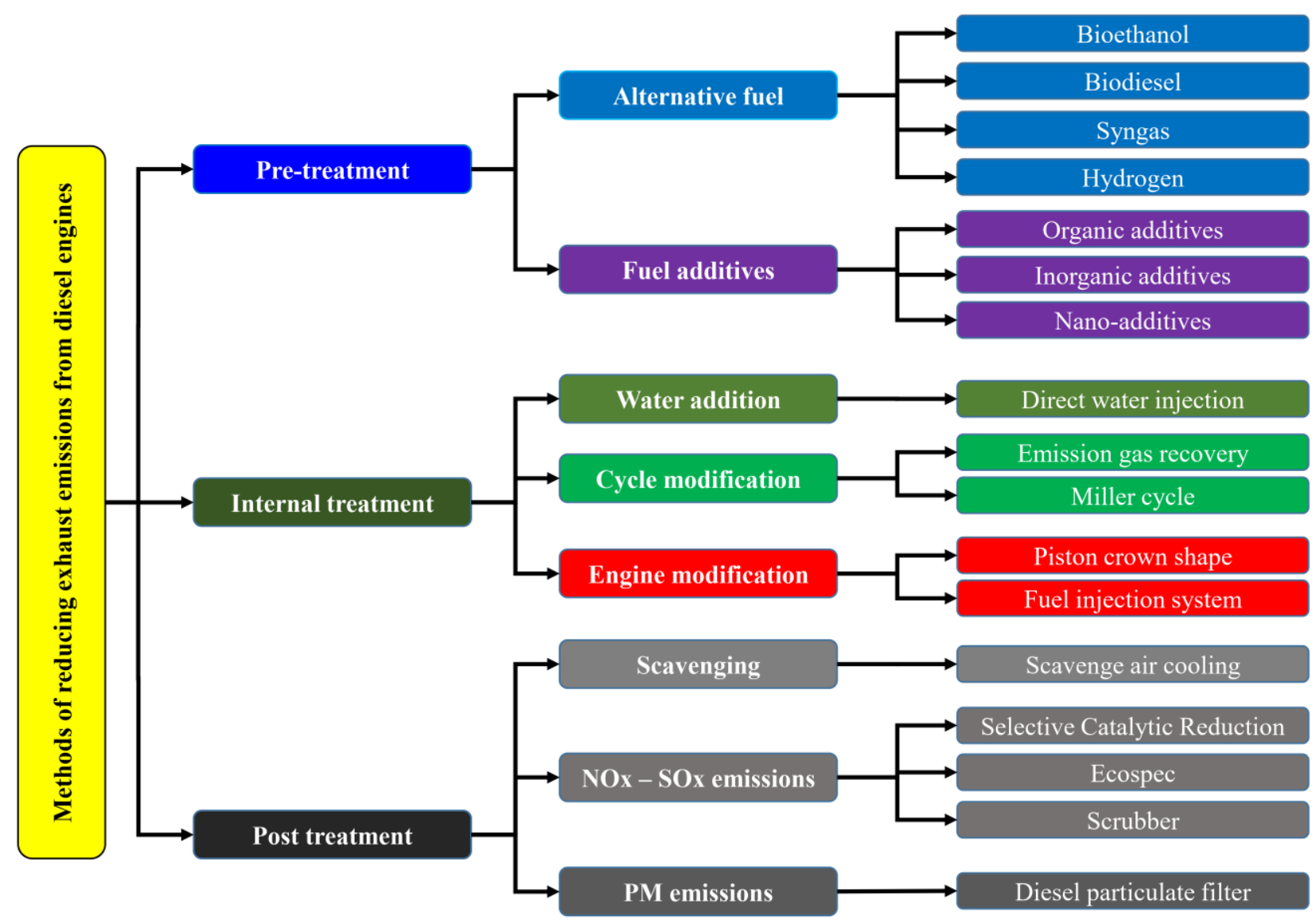

Fig. 1 Solution of reducing exhaust emission from diesel engines (Issa et al., 2019) 
On the other hand, the decline in global Bio-alcohol consumption during the widespread Covid-19 pandemic period led to a sharp decline in bio-alcohol refineries (Thomas et al., 2021). That has accelerated the processes of converting alcohol or ethanol into more versatile and value-added products, including ethers. As for ether additives, they are increasingly making important contributions to the strategy of sustainable alternative fuel use and environmental protection (Sezer, 2020). With very high cetane numbers, some ether additives are potential additives to be added to biofuels to increase the cetane number of blended fuels (Işık et al., 2020). Besides, popular ethers such as DEE and DME with low viscosity can overcome the high viscosity of biodiesel fuel to improve fuel injection quality. Recent studies have revealed that the addition of ether additives can improve important fuel properties, leading to improved combustion quality, brake thermal efficiency (BTE), brake specific fuel consumption (BSFC) and cylinder pressure (Sezer, 2019). More interestingly, blended fuels with the addition of these organic additives have provided environmental benefits by reducing emissions of $\mathrm{PM}, \mathrm{HCs}, \mathrm{CO}$ and $\mathrm{NOx}$ (Nižetić et al., 2021c)(Morales Bayetero et al., 2021).

In the past, typical organic additives have been evaluated and concluded in some basic aspects when considering their addition to conventional fuels and biofuels to supply internal combustion engines (Yetri et al., 2020). However, it is difficult to find articles evaluating the physicochemical properties of ether additives as well as their impact on engine performance and emission characteristics. Therefore, in this work, brief discussions of the ether additive production pathway from biomass are firstly presented to clarify the ether additive conversion technology and characteristics before the properties of typical ether additives was investigated. More importantly, the evaluation of brake thermal efficiency, brake specific fuel consumption, exhaust temperature, brake power as well as PM, NOx, CO and $\mathrm{HC}$ emissions were analyzed based on published literature which demonstrated research results on the addition of ether additives into diesel and biodiesel fuels for fuelling CI engine.

\section{Production of ether additives}

The production of DEE can be carried out by three different methods including (1) hydration of ethylene, (2) dehydration of ethanol with sulfuric acid catalysis and (3) dehydration of ethanol with a heterogeneous catalyst. With the first process, DEE is considered as a by-product from the hydration of ethylene because the conversion of ethylene is low (4-5\%) and has low DEE selectivity (Hidzir et al., 2014). Therefore, this technology contributes only a small amount of DEE produced. The second method is synthesized in a gas or liquid phase reactor with ethanol to sulfuric acid ratio of $1: 3$, achieving a conversion efficiency of up to $95 \%$ (Chaichana et al., 2019). However, the synthesis by this technique often produces acetaldehyde which makes DEE difficult to purify. The final DEE production was dehydration with heterogeneous acid catalysis such as zeolite H-Beta that converted $99 \%$ pure ethanol to DEE. If the raw material is hydrated ethanol, the resulting product still has traces of acetaldehyde, while using anhydrous ethanol, the purification of DEE is simpler because there is no acetaldehyde (Charoensuppanimit et al., 2021).

There are two technological processes for the production of DME including (1) direct process using biocatalysts, synthesized from syngas with a single reactor and (2) indirect process by including a 2 -step process, using methanol produced from syngas. Figure 2 shows the production of syngas from fossil fuel sources (coal, natural gas and petroleum) and biomass through steam reforming or gasification (de França Lopes et al., 2020)(Cheng et al., 2021). This process plays the most important role in the DME production process. The direct process has lower DME production costs due to higher $\mathrm{CO}$ conversion efficiency and simpler reactor construction (Yan et al., 2013). However, this process produces more greenhouse gas emissions. Therefore, it is not suitable for commercial DME production.

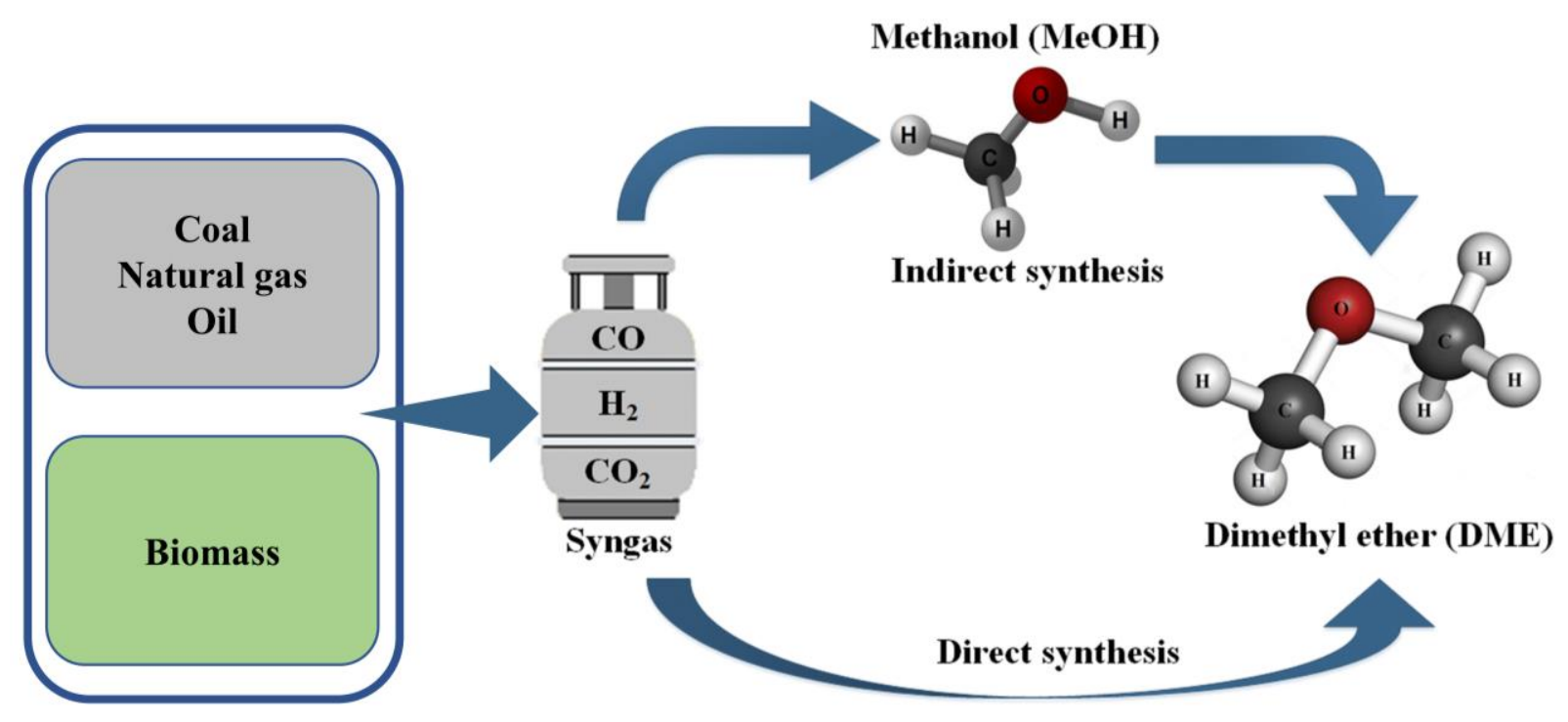

Fig. 2 The pathway of DME production (de França Lopes et al., 2020) 
Polyoxymethylene dimethyl ether (PODE) is usually produced through the gasification of biomass with catalytic acids with the intermediate conversion of syngas (Awad et al., 2020). In particular, the process of converting PODE from methanol is that it can recycle carbon dioxide, a viable solution in the methanol economy. Besides, on the decarbonization route, PODE synthesis can be done from $\mathrm{CO}_{2}$ and electricity. A comparative study was performed by Deutz et al. (Deutz et al., 2018) of two PODE production pathways including an indirect pathway based on the combination of methanol and formaldehyde and a direct pathway based on combining $\mathrm{CO}_{2}$ and hydrogen with catalysts. In general, recent studies on the assessment of the product life cycle of PODE have confirmed the adoption of green eco-energy, shown in Figure 3. PODE is an environmentally friendly fuel additive that can be produced from biomass (Viet and Tuan, 2021) or $\mathrm{CO}_{2}$ (Deutz et al., 2018), while the production cost is more competitive even cheaper than refining diesel from fossil resources (Aghbashlo et al., 2022).

\section{Properties of ether additives}

For studies using alternative fuels in internal combustion engines, the physicochemical properties of modified blends have key importance in changes of the combustion and emission characteristics (Van and Anh, 2019). However, the properties of the blended fuels are highly dependent on the properties of the base fuel and fuel additives. Therefore, providing physicochemical properties of additives needs to be detailed according to each key parameter such as density, viscosity, latent heat, boiling point, cetane number, lower heat value, selfignition temperature and oxygen content (Fayyazbakhsh and Pirouzfar, 2017). Typical properties of ether additives such as diethyl ether (DEE), dimethyl ether (DME), di-nbutyl ether (DNBE), 2-ethoxy ethyl ether (EXEE), ethyl ter-butyl ether (ETBE), 2-methoxy ethyl ether (MXEE), Ter-amyl ethyl ether (TAEE), Polyoxymethylene dimethyl ether (PODE), etc. are revealed in Table 1.
The cetane number is the rating assigned to diesel fuel to gauge its combustion quality. The cetane number of diesel fuel is a measure of the delay in the ignition timing of the fuel. A higher cetane number means a shorter ignition delay and complete combustion of the fuel in the combustion chamber (Yesilyurt and Aydin, 2020)(More et al., 2020)(Bui et al., 2020). This means that the fuel supplied to the engine has a higher cetane number resulting in a smoother running engine, better performance with more power and less harmful emissions. More interestingly, additives such as DEE (Sezer, 2011), DNBE (Kerschgens et al., 2016), EXEE (Kumar et al., 2018), MXEE (Ommi et al., 2009) have very high cetane number values, 2-3 times higher than that of diesel fuel. The presence of these additives in the modified fuel can significantly contribute to improved combustion quality and emissions of CI engines. Furthermore, oxygen content in oxygenated additives is an outstanding advantage of ether-based additives. Additives such as DME (Zhao et al., 2014) and MEA (Yanfeng et al., 2007) have an oxygen content of up to $1 / 3$ of the atomic mass, which increases the concentration of atomic oxygen in the fuels blended with the additive (Khalife et al., 2017)(Sadhik Basha, 2018)(Hoang, 2021). The highest oxygen content of the ether additives was recorded as high as $47 \%$ for PODE (Barro et al., 2019). Thus, the combustion quality in the cylinder is significantly improved along with the reduction of particulate emission components. For instance, a fairly common, low-cost ether compound, a potential alternative fuel candidate for CI engines, is DME that has a fairly high cetane number. It has a low self-ignition temperature so it can vaporize and burn instantly (Le et al., 2021). More interestingly, with its high oxygen content, about $35 \%$ by weight of DME, while the absence of C-C bonds, it is possible to promote clean and smokeless combustion (Bauer and Kruse, 2019). Besides, with a very low boiling point, it vaporizes immediately after being injected into the cylinder, it is suitable for fuel injection pressure from $50-150 \mathrm{MPa}$, so the CI engine does not need to change the fuel injection system (Maji et al., 2014).

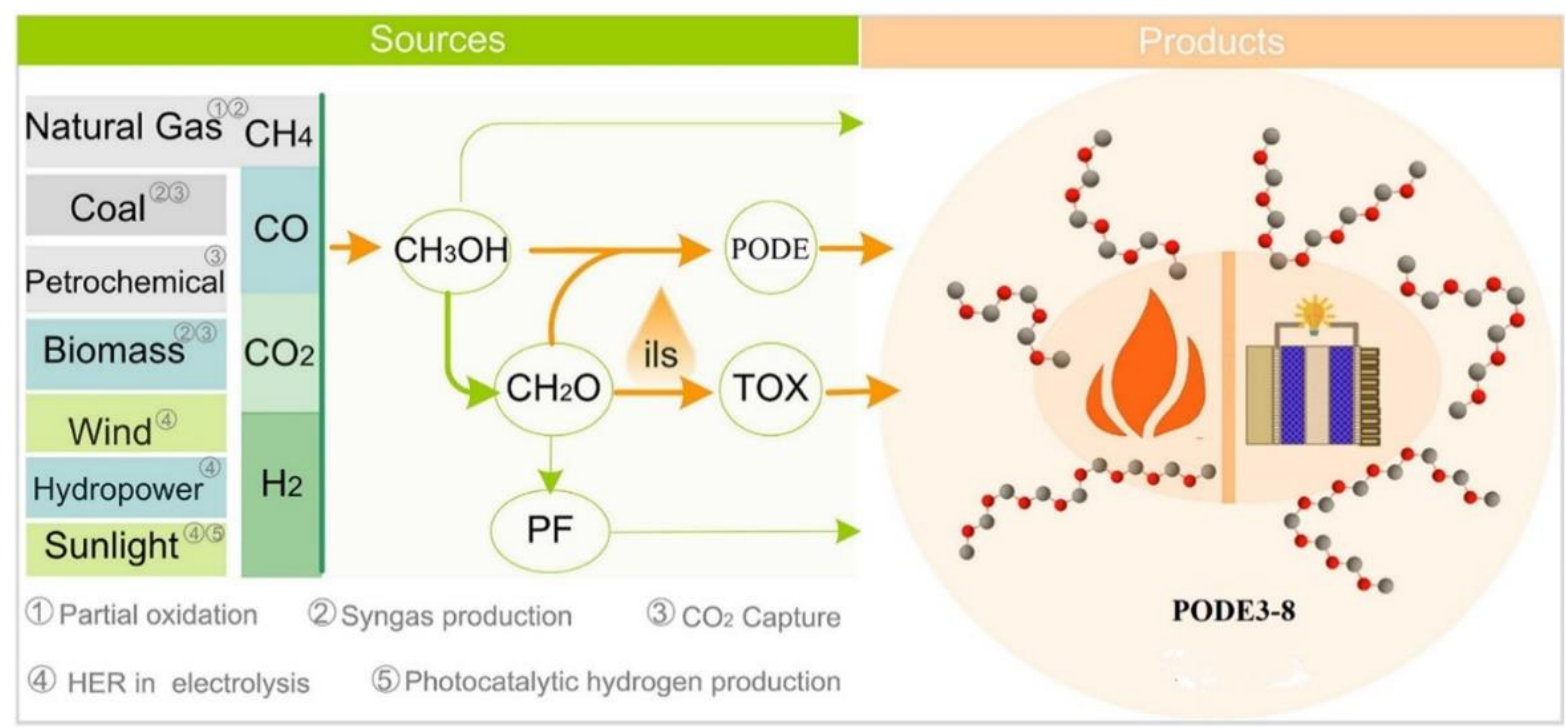

Fig. 3 Pathways of PODE production (Awad et al., 2020) 
Table 1.

Physico-chemical and combustion properties ether additives

\begin{tabular}{|c|c|c|c|c|c|c|c|c|c|c|}
\hline Additive & $\begin{array}{l}\text { Molecular } \\
\text { formula }\end{array}$ & $\begin{array}{l}\text { Density } \\
\left(\mathrm{kg} / \mathrm{m}^{3}\right)\end{array}$ & $\begin{array}{c}\text { Viscosity } \\
\text { (cSt) }\end{array}$ & $\begin{array}{l}\text { Latent heat } \\
\qquad(\mathrm{kJ} / \mathrm{kg})\end{array}$ & $\begin{array}{l}\text { Boiling } \\
\text { point } \\
\left({ }^{\circ} \mathrm{C}\right)\end{array}$ & $\begin{array}{l}\text { Cetane } \\
\text { number }\end{array}$ & $\begin{array}{c}\text { Oxygen } \\
\text { content } \\
(\%)\end{array}$ & $\begin{array}{l}\text { Lower heating } \\
\text { value }(\mathrm{MJ} / \mathrm{kg})\end{array}$ & $\begin{array}{l}\text { Auto-ignition } \\
\text { temperature } \\
\left({ }^{\circ} \mathrm{C}\right)\end{array}$ & Ref. \\
\hline DEE & $\mathrm{C}_{4} \mathrm{H}_{10} \mathrm{O}$ & 710 & 1.21 & 356 & 34.6 & 125 & 21 & 33.9 & 160 & (Sezer, 2011) \\
\hline DME & $\mathrm{CH}_{3} \mathrm{OCH}_{3}$ & 667 & - & - & -25 & 61 & 35 & 27 & 239 & $\begin{array}{l}\text { (Zhao et al., } \\
\text { 2014) }\end{array}$ \\
\hline DNBE & $\mathrm{C}_{8} \mathrm{H}_{18} \mathrm{O}$ & 770 & & 345 & 144 & 100 & - & 32 & 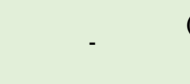 & $\begin{array}{l}\text { (Kerschgens et } \\
\text { al., 2016) }\end{array}$ \\
\hline EEA & $\mathrm{C}_{6} \mathrm{H}_{12} \mathrm{O}_{3}$ & 975 & 1.32 & $\cdot$ & 156 & 61 & 17 & - & 379 & $\begin{array}{l}\text { (Sudeshkumar } \\
\text { et al., 2012) }\end{array}$ \\
\hline EGM & $\mathrm{C}_{4} \mathrm{H}_{8} \mathrm{O}_{3}$ & 1009.2 & 1.8 & - & 187 & 0.1 & 46 & 25.9 & - & $\begin{array}{c}\text { (Lin and } \\
\text { Huang, 2003) }\end{array}$ \\
\hline ETBE & $\mathrm{C}_{6} \mathrm{H}_{14} \mathrm{O}$ & 742 & 0.48 & - & 70 & - & 16 & 36 & - & $\begin{array}{l}\text { (de Menezes et } \\
\text { al., 2006) }\end{array}$ \\
\hline EXEE & $\mathrm{C}_{8} \mathrm{H}_{18} \mathrm{O}_{3}$ & 910 & & - & 189 & 126 & 30 & - & 174 & $\begin{array}{c}\text { (Kumar et al., } \\
\text { 2018) }\end{array}$ \\
\hline MXEE & $\mathrm{C}_{6} \mathrm{H}_{14} \mathrm{O}_{3}$ & 950 & 1.08 & - & 162 & 124 & 36 & - & 190 & $\begin{array}{l}\text { (Ommi et al. } \\
\text { 2009) }\end{array}$ \\
\hline MEA & $\mathrm{C}_{5} \mathrm{H}_{10} \mathrm{O}_{3}$ & 1010 & 1.10 & - & 143 & - & 41 & 21 & 392 & $\begin{array}{c}\text { (Yanfeng et al., } \\
\text { 2007) }\end{array}$ \\
\hline TAEE & $\mathrm{C}_{7} \mathrm{H}_{16} \mathrm{O}$ & 767 & 0.41 & - & 102 & - & 14 & - & - & $\begin{array}{l}\text { (Aydin et al., } \\
\text { 2020) }\end{array}$ \\
\hline $\operatorname{PODE}_{(1-6)}$ & $\mathrm{C}_{2} \mathrm{H}_{6} \mathrm{O}\left(\mathrm{CH}_{2} \mathrm{O}\right)_{\mathrm{n}}$ & $860-1130$ & $0.36-2.36$ & - & $42-280$ & $74-128$ & $42-49$ & $17.5-22.4$ & - & $\begin{array}{c}\text { (Awad et al., } \\
2020)\end{array}$ \\
\hline
\end{tabular}

However, the lower calorific value is lower than that of conventional diesel fuel, which increases the specific fuel consumption of the engine using the fuel blended with ether additives (Bragadeshwaran et al., 2018)(Nižetić et al., 2021a). In addition, the inherent disadvantage of oxygenated additives, their kinematic viscosity is too low, which seriously affects the lubricating ability of the fuel (Lautenschütz et al., 2016)(Le and Hoang, 2017). As a result, the corrosion rate in the injector and piston ring increases significantly, adversely affecting engine durability. In a study by Rakopoulos et al. (Rakopoulos et $a l ., 2013)$, the use of additives such as DEE and ethanol in diesel fuel reduced the kinematic viscosity of the blended fuel, increasing the wear of the fuel pump and injector. Another emerging ether additive for biofuels is DBE, which is produced from biomass. It has low viscosity and density, which when mixed with biodiesel improves the characteristic properties of biofuel, leading to improved injection parameters. In the study by $\mathrm{Fu}$ et. al (Fu et al., 2019 ), adding $15 \%$ vol. and $30 \%$ vol. of DBE into biofuels with DBE15 and DBE30 respectively, result in reduced penetration, also increased spray cone angle and maximum spray width. In another study from Tang et al. (Tang et al., 2017), the experimental results were also similar, with $30 \%$ DBE blended with $70 \%$ biodiesel, the viscosity and density of the blended fuel decreased, increasing the angle it sprays and the spray area (Hoang, 2019).

Studies using oxygen-rich ether additives to blend with the pyrolysis waste plastic oil (WPO) have attracted much attention from researchers. A recent study by
Gnanamoorthi and Murugan (Gnanamoorthi and Murugan, 2019) showed that DEE and MEA were added to WPO to improve the properties of the modified blends and combustion characteristics. MEA additives include both ethers and esters, with high oxygen content to enhance combustion in the cylinder. Moreover, its boiling point and flash point are similar to diesel fuel, for which DEE has a much lower value (Minh and Anh, 2018). While the outstanding advantage of DEE is its very high cetane number and lower viscosity compared to diesel. Therefore, incorporating the addition of DEE and MEA into WPO could have resulted in a more stable, homogenous blend fuel and with physicochemical properties suitable for fuels fed to CI engines without any adjustments.

The influences of ethers such as ETBE and TAEE on density, volatility, viscosity, characteristics at cold temperatures, the cetane number of diesel fuel were investigated in the study of Menezes et al. (de Menezes et $a l ., 2006)$. The study obtained that the operation of TAEE and ETBE is similar to co-solvents of ethanol in diesel. Furthermore, the evaluation of physicochemical properties obtained reasonable results and the efficiency of the engine is improved significantly in tests with $5 \% \mathrm{v} / \mathrm{v}$ of TAEE concentration (Aydin et al., 2020). However, the flashpoint and distillation curve which represent volatility characteristics are changed and the cetane number decline due to ETBE.

Finally, the auto-ignition temperature of ether additives is lower than that of diesel fuel, which can increase flammability in storage and use. Therefore, many factors should be considered in the selection of suitable 
ether additives to improve the physicochemical properties of experimental or commercial fuels. In this, factors such as safety potential and cost should be considered in addition to the properties shown from standard measurement methods.

\section{Impact of ether additives on engine performance and emission characteristics}

\subsection{Engine performances}

The physicochemical properties of the ether additive have a significant impact on the characteristics of modified fuels as well as the combustion behaviours and engine performances. For instance, studies of Mohan et al. (Mohan et al., 2017) and Jawre et al. (Jawre et al., 2016) have revealed that the increased ignition delay caused by the addition of DEE to diesel fuel reduced the injection time of the blended fuel. Furthermore, the latent heat of blends with DEE is higher. Thus, it was necessary to prolong the fuel injection time to ensure the release the same of energy. However, More et al. (More et al., 2020) has confirmed that a high cetane number is the main cause of an increased ignition delay. A study by Ibrahim (Ibrahim, 2016), the blend of DEE and neat diesel has improved engine performance under all load conditions. With up to $15 \%$ DEE participation in the test fuel, the maximum brake thermal efficiency increased by $7.2 \%$ while the lowest specific fuel consumption decreased by $6.7 \%$. Kumar et. al (Kumar et al., 2020) performed a test on a VCR (variable compression ratio) diesel engine using mixed fuel D-NM2.5-DEE7.5 (with 7.5\%DEE and 90\% diesel). Modified blends with BTE rose by $17.4 \%$ while BSFC fell by $19.5 \%$. The results revealed the role of DEE in improving the engine characteristics and combustion behavior of the blends compared to pure diesel fuel.

An investigation on CRDI engines by Gnanamoorthi and Murugan (Gnanamoorthi and Murugan, 2019), using diesel fuels, pyrolysis waste plastic oil (WPO) and their mixtures with DEE and MEA have evaluated the role of additives to the ability to improve combustion and engine performance. Indeed, the brake thermal efficiency (BTE) for D50W40DEE10 and D50W50 has been 3.6\% and 4.8\% lower compared to pure diesel, while BTE for

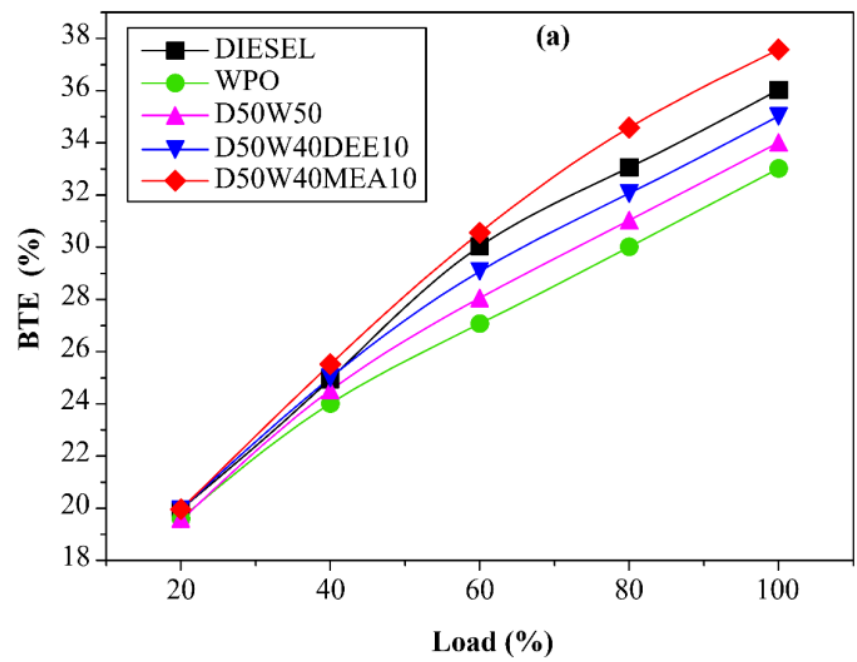

D50W40MEA10 has increased by $5.2 \%$ compared to pure diesel, shown in Figure 4a. Furthermore, the exhaust gas temperature (EGT) of WPO is the highest, because the incomplete combustion of WPO fuel takes longer and can burn on the discharge process. EGT for D50W50 increased by $11.2 \%$ compared to diesel. More interestingly, WPO was mixed with DEE and MEA, the role of high oxygen content improved complete combustion. EGT for D50W40DEE10 and D50W40MEA10 have seen a decrease of $10.1 \%$ and $10.9 \%$ compared to WPO respectively, depicted in Figure 4b.

More et al. (More et al., 2020) investigated the diesel engine characteristics for different volume percentages of diethyl ether (DEE) adding into cooking oil (RUCO) biodiesel and diesel blends. In this work, several pilot experimentations commenced to be performed with diesel and blended B20 before adding 0.8\%, 1.6\%, 2.4\%, 3.2\%, and $4 \%$ of DEE into biodiesel/diesel. This work abided by the IS standards for the estimation of the various properties of biodiesel blends. Investigated results remarked that the density, viscosity, calorific value, and flash point have a dropdown trend due to the concentration of DEE increased which also ascended cetane number. Examination of all fuel samples was conducted on a water-cooled diesel engine at six load modes and a fixed speed. The examination obtained that as contrasting with diesel fuel, the rise of the BTE was up to $16.06 \%$ while the reductant of BSFC (Brake specific fuel consumption) was up to $4.12 \%$ for the blend of $0.8 \%$ concentration of DEE. Double blends of DEE-diesel fuel (D95DEE5 and D90DEE10) and four blends of DEEethanol-diesel fuel (D90DEE5E5, D85DEE5E10, D85DEE10E5, and D80DEE10E10) was investigated in the experiment of Paul et al. (Paul et al., 2015). The engine used in this study is a 4-stroke diesel engine, singlecylinder. D95DEE5 (5\% of DEE and 95\% of diesel fuel) showed an increment of the BTE of the engine. In contrast, D90DEE10 (10\% concentration of DEE in Diesel) reduced the BTE of the engine. Although brake-specific energy consumption (BSEC) witnessed a declining trend with D95DEE5, adding more DEE concentration visibly climbed the BSEC of the engine.

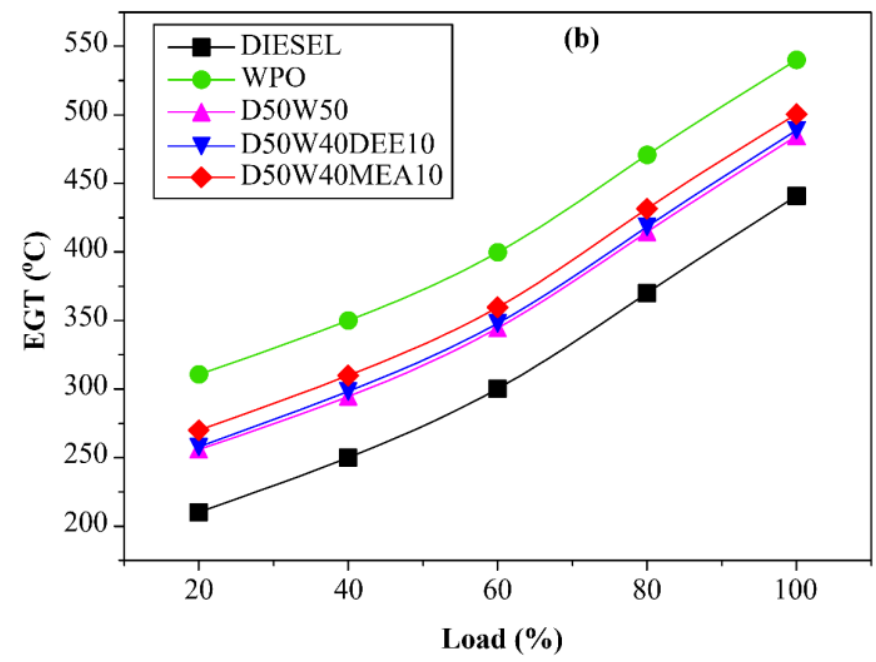

Fig. 4 Change of BTE (a) and EGT (b) for various blends at different loads (Gnanamoorthi and Murugan, 2019) 
D80DEE10E10 blend (10\% DEE and 10\% ethanol with diesel) got the best performance among DEE-diesel fuel mixed with ethanol, which improved the BTE by $15.94 \%$ and decreased BSEC by $14.26 \%$ compared to pure Diesel fuel at the same load equivalent of $1.8 \mathrm{~kW}$. In most of the research studies, the advantage of ether additives was to assist in optimizing the performance and minimizing the emissions due to better physicochemical properties such as cetane number and ignition quality. In addition, a study by Murat et al. (Yesilyurt and Aydin, 2020) on the addition of DEE to B20 biodiesel blends at 2.5\%, 5\%, 7.5\% and $10 \%$ vol. fueled for a 4 -stroke, single-cylinder, direct injection diesel engine at variable loads and fixed speed. In terms of engine performance, brake thermal efficiency has been reduced by $17.4 \%$ while specific fuel consumption has increased by approximately $30 \%$ at the maximum DEE addition. The lower calorific value of DEE affects the power generated when a certain amount of fuel is burned. This explains the increase in BSFC when the presence of DEE is more in the secondary and tertiary fuels, and in agreement with similar studies by Das et al.(Das et al., 2018), as shown in Figure 5a. Furthermore, the low cetane number of DEE is the main cause of the shortening of the ignition delay, which has resulted in poor mixing of the fuel-air mixture. As a result, brake specific energy consumption (BSEC) recorded an increase in all secondary and tertiary fuels compared to pure diesel or pure biodiesel. Figure 5b depicts this trend for BSEC. A survey to evaluate the effect of DEE on BSEC was carried out by Rakopoulos et al. (Rakopoulos et al., 2012) also agree on the decrease in energy density of the modified fuels.

More interestingly, the reaction of isobutene and isoamylenes with ethanol results in the formation of Ethers additives which are semi-renewable products (de Menezes et al., 2006). It is not difficult to burn ether additives which particularly include Ter-amyl ethyl ether (TAEE), ethyl ter-butyl ether (ETBE), 2-ethoxy ethyl ether (EXEE), 2-methoxy ethyl ether (MXEE), dimethyl ether (DME), diethyl ether (DEE), di-n- butyl ether (DNBE), etc. A study by Murat et al. (Yesilyurt and Aydin, 2020) aimed to examine experimentally engine characteristics with a variety of diethyl ether (DEE) fractions which play an oxygenated fuel additive role in cottonseed oil biodieseldiesel fuel blends. The initial step was to carry out several tests with diesel and blended B20. After that, the ternary blends were prepared by mixing $2.5 \%, 5 \%, 7.5 \%$, and $10 \%$ of DEE by volume into biodiesel-diesel fuel. A singlecylinder, four-stroke, and direct-injection diesel engine were used to test whole the fuel samples under conditions of various engine loads and fixed engine speed. The obtained results from the experiment revealed that compared to diesel fuel, BTE was dropped by $17.39 \%$ whereas BSFC was raised by $29.15 \%$ with blending $10 \%$ of DEE. Besides, in order to improve the use of waste cooking oil (WCO) for DICI engines, Chaudhary et al. (Chaudhary and Gakkhar, 2020) tested the addition of DEE additive to WCO at the ratios of $5 \%, 10 \%$ and $15 \%$ on the engine at $100 \%$. of load and steady speed of $1600 \mathrm{rpm}$. The results recorded an $8.5 \%$ improvement in engine performance when WCO fuel was mixed with $15 \%$ DEE.

The non-biodegradability of waste plastic is turning it into a terrifying threat to the Earth. The good news is that many man-made methods can treat plastic waste to convert them into value-added products like waste plastic pyrolysis oil. However, it is difficult for pure waste plastic pyrolysis oil to replace diesel because of its lower thermal efficiency because the high viscosity of WPO leads to poorer evaporation and combustion (Noor et al., 2018). Furthermore, using 100\% WPO has increased the number of toxic emissions due to its very high aromatic content. Although the WPO tests were blended with pure diesel fuel, performance and emissions characteristics were still not as good as pure diesel fuel (Devaraj et al., 2015). Therefore, the use of additives has been seen as an effective solution to overcome the problems related to the viscosity and density of WPO. In the study by Kaimal et al. (Kaimal and Vijayabalan, 2016), WPO-diesel blends with added DEE additive at the rate of 5\%, 10\% and $15 \%$ by volume were supplied to CI engines to evaluate the dynamic performance. muscle. Brake specific fuel consumption is lower compared to diesel fuel. Moreover, the brake thermal efficiency has also been higher than pure WPO. According to Gnanamoorthi et al. (Gnanamoorthi and Murugan, 2019), in order to improve engine performance and reduce fuel consumption, a survey on CRDI engines was conducted with blended fuels between diesel and waste plastic pyrolysis oil with the addition of oxygen-rich additives include DEE and MEA.
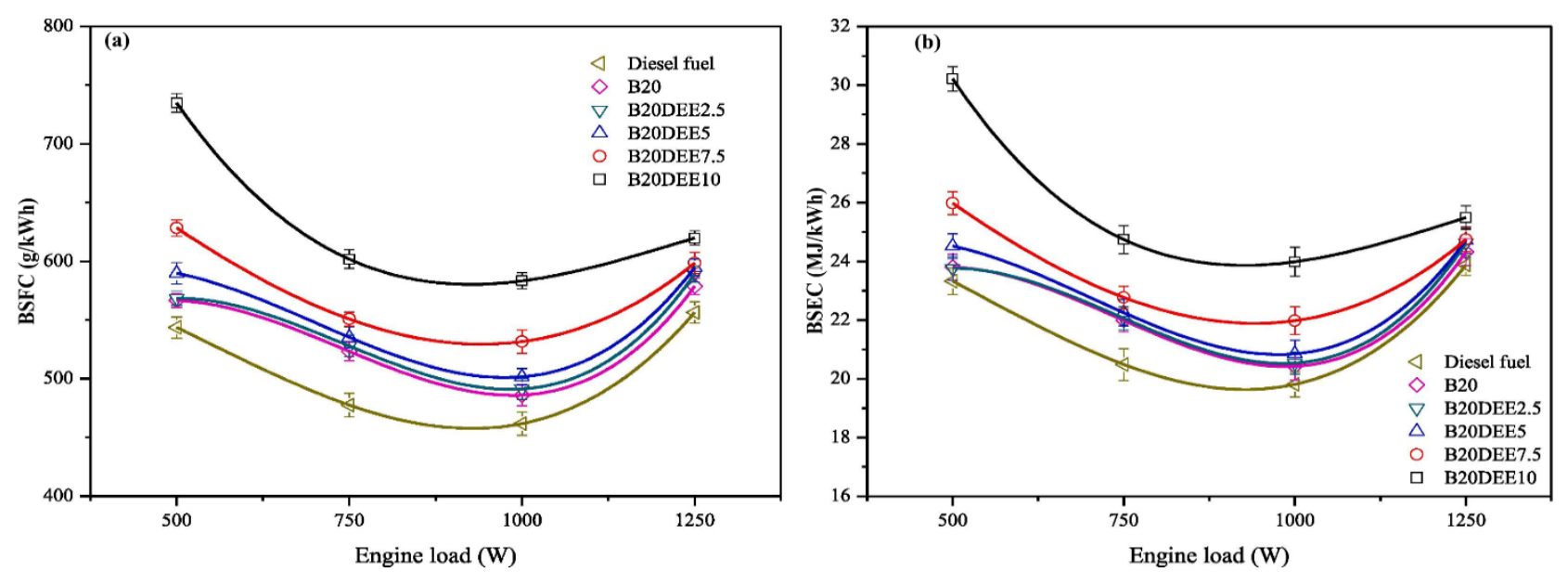

Fig. 5 Change of BSFC (a) and BSEC (b) of modified fuels with DEE at different loads (Yesilyurt and Aydin, 2020) 
In terms of brake specific fuel consumption, using pure WPO recorded the highest value, while when BSFC was gradually reduced in the order of D50W50, D50W40DEE10 and D50W40MEA10, but higher in comparison with pure diesel. In general, the exhaust gas temperature of WPO was the highest due to lower volatility and higher viscosity resulting in incomplete combustion. Despite the addition of oxygen-rich additives, the exhaust temperature of D50W40MEA10 was $12.2 \%$ higher than that of pure diesel. On the other hand, the exhaust temperature of D50W40MEA10 was recorded $11.4 \%$ higher than that of D50W40DEE10 because the oxygen content in MEA was higher than that of DEE.

Several recent studies have confirmed that besides the advantages of alcohol and ether additives, P-series glycol ether additives are emerging as potential organic additive candidates. The most prominent is the 2-Ethoxy Ethyl Acetate (EEA) additive, which can be blended into diesel fuel to improve engine performance and reduce environmental pollution. Sood et al. (Sood et al., 2014) performed tests on 4-stroke, single-cylinder CI engines using D0, D95EED5, D90EED10 and D85EED15 fuels (EED is blended with diesel (D0) in $5 \%, 10 \%$ and $15 \%$ by volume). The results revealed the ability to increase brake power and brake thermal efficiency as using the D90EEA10, at full load, the brake power increased by $7.6 \%$, the brake thermal efficiency increased by $7.2 \%$ compared to diesel fuel. Furthermore, the solution of adding additives to traditional fuels brings many benefits and advantages to engine characteristics. Indeed, a study by Rao et al. (Rao et al., 2020) reported the positive effects of EEA and NM additives in blended fuels such as DEEA10-NM2, D-EEA15-NM2, D-EEA20-NM2 and diesel to BTE and BSFC of CI engines running under variable load conditions. In comparison with test fuels, two fuels blended $10 \% \mathrm{EEA}$ and $15 \% \mathrm{EEA}$ along with $2 \% \mathrm{NM}$ were more prominent. BTE increased $1.78 \%$ and $0.94 \%$ respectively using D-EEA10-NM2 and D-EEA15-NM2, however, BSFC increased approximately $10 \%$ and $13 \%$ for those 2 test fuels at full load (Nižetić et al., 2021b).

An effort of Sukjit et al. (Sukjit et al., 2012) improved the stability and lubricity of fuel blends and characteristics of combustion by employing methyl ester as a tertiary additive in alcohol (ethanol and butanol)diesel blends in CI engine. As shown by the results in their work, $15 \%$ of all methyl esters in blend could avoid phase separation of fuel blends and retained wear scar diameter of the alcohol-diesel blends following the requirement of the lubricity standard (Labeckas et al., 2018). They concluded that the short carbon chain length and saturated methyl esters are suggested for the improvement of alcohol-diesel blends. Ethylene glycol mono acetate (EGM) is considered as a possible approach to reduce harmful emissions from marine diesel engines (Xuan et al., 2021). EGM has an atomic mass of 104, made up of the elements $\mathrm{C}, \mathrm{H}$ and $\mathrm{O}$ accounting for $46 \%$ by weight. The addition of EGM additive to diesel fuel can enhance the oxidation reactions during combustion, resulting in less particulate and toxic gas emission products. In the study of Lin et al. (Lin and Huang, 2003), a 4-stroke, 4-cylinder, the direct-injection marine diesel engine was supplied D100, D95EGM5 and D90EGM10 to evaluate engine performance such as BSFC and EGT. With variable speed and fixed torque, BSFC has increased in the proportion of EGM addition, mainly because EGM has a lower calorific value compared to diesel, while EGT recorded the opposite trend.

The combination of different organic additives to blend with diesel fuel is considered as a solution that takes advantage of the advantages of each type of additive. In a study by Wang et al. (Yanxia and Yongqi, 2007), dimethyl carbonate (DMC) an additive containing 53.3\% oxygen was mixed with diesel fuel with the addition of EGM additive, blend fuels included DMC15, DMCEGM5, DMCEGM10, DMCEGM15 AND DMCEGM20. In terms of engine performance, power was reduced with the increase of DMC and EGM additions, because the energy density of the 2 additives was lower than that of diesel. In comparison with diesel fuel, maximum power reductions were recorded of $2 \%, 4 \%, 6 \%$ and $8 \%$ for DMCEGM5, DMCEGM10, DMCEGM15 and DMCEGM20 respectively. DME is a potential renewable fuel with a very high cetane number, so it can be used in blending with secondary and tertiary fuel blends to improve the cetane number of biodiesel (Wang and Yao, 2020). In a study by Joy et al. (Joy et al., 2019), two fuel samples formed from cashew nut shell oil biodiesel with $10 \%$ and $20 \%$ DME were tested on a 4-stroke 1-cylinder diesel engine to investigate engine characteristics. The results revealed that the BTE and BSFC of CBD80DME20 and CBD90DME10 were both increased compared to diesel and CBD100. Indeed, in a comparison of CBD80DME20 and biodiesel, BTE increased by $1.6 \%$ and BSFC decreased by $4.1 \%$, Figure 6 shows that change. Table 2 shows the significant effects of ether additives on engine performance such as BTE, BSFC and ETG.
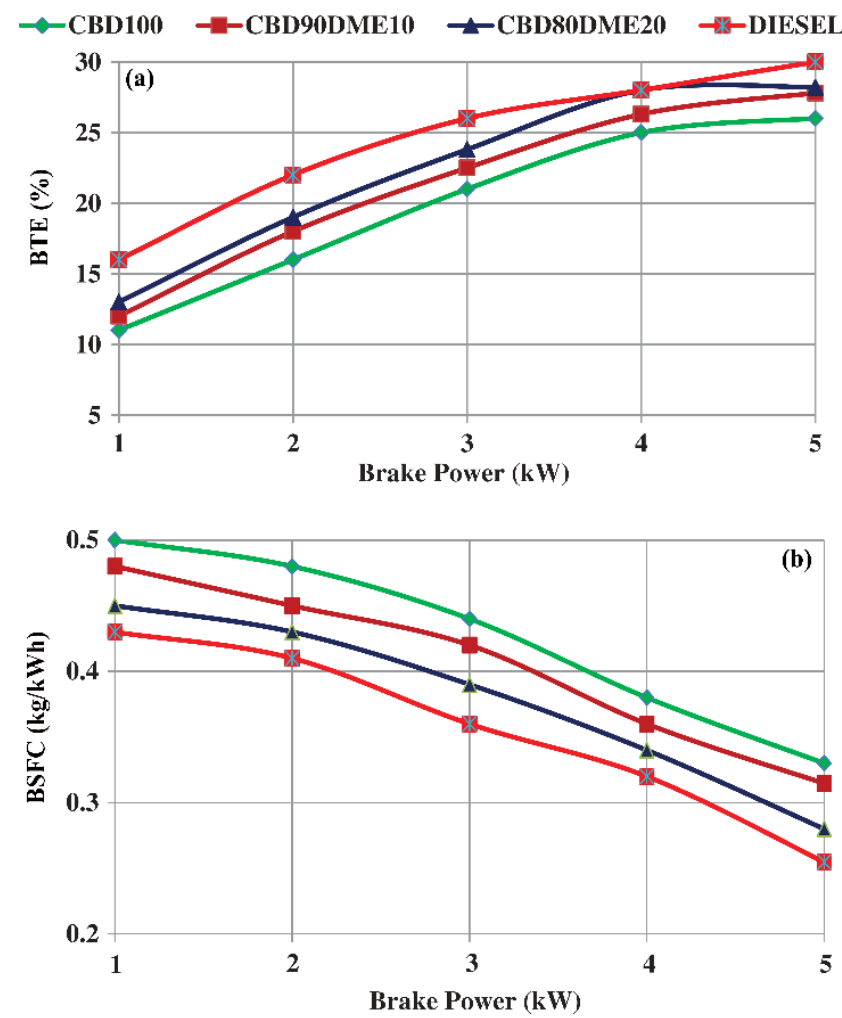

Fig. 6 The differences in BTE (a) and BSFC (b) of blends with DME at various brake power (Joy et al., 2019) 
Table 2

Summary of the overall performance in diesel engine using ether additives

\begin{tabular}{|c|c|c|c|c|c|c|}
\hline Additive & Concentration & Test Condition & BTE & BSFC & EGT & References \\
\hline \multirow[t]{5}{*}{ DEE } & $5 \% \mathrm{DEE}$ & $\begin{array}{l}\text { Different loads }(20,40, \\
60,80 \text { and } 100 \%)\end{array}$ & $\begin{array}{l}\uparrow \text { compared to diesel } \\
\text { fuel and other blends }\end{array}$ & - & $\begin{array}{l}\uparrow \text { compared to diesel } \\
\text { fuel and other blends }\end{array}$ & $\begin{array}{l}\text { (Mohanan et } \\
\text { al., 2003) }\end{array}$ \\
\hline & $10 \% \mathrm{DEE}$ & Injection timing at $27^{\circ}$ & $\downarrow$ compared to diesel & - & Close to diesel fuel & \\
\hline & $15 \% \mathrm{DEE}$ & $\begin{array}{l}\text { Engine speed at } 1500 \\
\text { rpm }\end{array}$ & $\begin{array}{l}\downarrow \text { compared to diesel } \\
\text { fuel and } 10 \% \mathrm{DEE}\end{array}$ & - & Close to diesel fuel & \\
\hline & $20 \%$ DEE & & $\begin{array}{l}\uparrow \text { compared to diesel } \\
\text { fuel at loads of } 60 \text { to } \\
100 \% \text { but } \downarrow \text { at other } \\
\text { loads }\end{array}$ & - & $\begin{array}{l}\downarrow \text { compared to diesel } \\
\text { fuel }\end{array}$ & \\
\hline & $25 \% \mathrm{DEE}$ & & $\begin{array}{l}\uparrow \text { compared to diesel } \\
\text { fuel at loads of } 60 \text { to } \\
100 \% \text {, but } \downarrow \text { at }\end{array}$ & - & $\begin{array}{l}\downarrow \text { compared to diesel } \\
\text { fuel }\end{array}$ & \\
\hline \multirow[t]{4}{*}{ DEE } & B4 (4\%) & $\begin{array}{l}\text { Different loads }(25,50 \text {, } \\
75 \text { and } 100 \%)\end{array}$ & $\begin{array}{l}\text { Not change much } \\
\text { compared to diesel fuel }\end{array}$ & - & $\begin{array}{l}\uparrow \text { compared to diesel } \\
\text { fuel but lower than B5 }\end{array}$ & $\begin{array}{l}\text { (Kapilan et } \\
\text { al., 2008) }\end{array}$ \\
\hline & B5 (5\%) & & $\begin{array}{l}\uparrow \text { compared to diesel } \\
\text { fuel and other blends }\end{array}$ & - & $\begin{array}{l}\uparrow \text { compared to diesel } \\
\text { fuel and other blends }\end{array}$ & \\
\hline & $\mathrm{B} 6(6 \%)$ & & $\begin{array}{l}\uparrow \text { compared to diesel } \\
\text { fuel }\end{array}$ & - & $\begin{array}{l}\uparrow \text { compared to diesel } \\
\text { fuel but lower than B5 }\end{array}$ & \\
\hline & B7 (7\%) & & $\begin{array}{l}\uparrow \text { compared to diesel } \\
\text { fuel at } 25 \text { and } 50 \% \\
\text { load, } \downarrow \text { at } 75 \text { and } 100 \% \\
\text { load. }\end{array}$ & - & $\begin{array}{l}\text { Not change much } \\
\text { compared to diesel } \\
\text { fuel }\end{array}$ & \\
\hline \multirow[t]{2}{*}{ DME } & $14 \%$ vol. & $\begin{array}{l}\text { Different EGR rates }(9, \\
18 \text { and } 27 \%)\end{array}$ & $\begin{array}{l}\uparrow \text { compared to diesel } \\
\text { fuel }\end{array}$ & $\begin{array}{l}\downarrow \text { compared to } \\
\text { diesel fuel }\end{array}$ & & $\begin{array}{l}\text { (Zhao et al., } \\
2014)\end{array}$ \\
\hline & $30 \%$ vol. & $\begin{array}{l}\text { Different BMEP }(0.25 \\
\text { and } 0.5 \mathrm{MPa})\end{array}$ & $\begin{array}{l}\uparrow \text { compared to diesel } \\
\text { fuel and } 14 \% \text {. }\end{array}$ & $\begin{array}{l}\downarrow \text { compared to } \\
\text { diesel fuel and } \\
14 \% \text {. }\end{array}$ & & \\
\hline \multirow[t]{6}{*}{ DEE } & DE2D & $\begin{array}{l}\text { Different BMEP }(0.1 \text {, } \\
0.2,0.3,0.4 \text { and } 0.45 \\
\mathrm{MPa})\end{array}$ & $\begin{array}{l}\uparrow \text { compared to diesel } \\
\text { fuel but } \downarrow \text { significantly } \\
\text { at BMEP of } 0.45 \mathrm{MPa}\end{array}$ & close to diesel fuel & $\begin{array}{l}\uparrow \text { compared to diesel } \\
\text { fuel but only } \downarrow \text { at } 0.3 \text { - } \\
0.45 \mathrm{MPa} \text { of BMEP }\end{array}$ & $\begin{array}{l}\text { (Patil and } \\
\text { Thipse, } \\
\text { 2015) }\end{array}$ \\
\hline & DE5D & & Not change & $\begin{array}{l}\uparrow \text { compared to } \\
\text { diesel fuel }\end{array}$ & $\begin{array}{l}\uparrow \text { compared to diesel } \\
\text { fuel but only lower at } \\
0.45 \mathrm{MPa} \text { of BMEP }\end{array}$ & \\
\hline & DE8D & & $\begin{array}{l}\uparrow \text { compared to diesel } \\
\text { fuel }\end{array}$ & close to diesel fuel & $\begin{array}{l}\downarrow \text { compared to diesel } \\
\text { fuel but } \uparrow \text { compared to } \\
\text { DE15D }\end{array}$ & \\
\hline & DE10D & & close to diesel fuel & $\begin{array}{l}\uparrow \text { compared to } \\
\text { diesel fuel }\end{array}$ & $\begin{array}{l}\downarrow \text { compared to diesel } \\
\text { fuel } \uparrow \text { compared to } \\
\text { DE15D }\end{array}$ & \\
\hline & DE15D & & $\begin{array}{l}\uparrow \text { compared to diesel } \\
\text { fuel and other DEE- } \\
\text { diesel }\end{array}$ & $\begin{array}{l}\downarrow \text { compared to } \\
\text { diesel fuel and } \\
\text { other DEE-diesel. }\end{array}$ & $\begin{array}{l}\downarrow \text { compared to diesel } \\
\text { fuel and other DEE- } \\
\text { diesel. }\end{array}$ & \\
\hline & DE20D & & close to diesel fuel & $\begin{array}{l}\uparrow \text { compared to } \\
\text { diesel fuel }\end{array}$ & $\begin{array}{l}\downarrow \text { compared to diesel } \\
\text { fuel } \uparrow \text { compared to } \\
\text { DE15D. }\end{array}$ & \\
\hline DME & $\begin{array}{l}\text { Equivalence } \\
\text { ratio from } 0.4 \text { to } \\
0.7\end{array}$ & $\begin{array}{l}\text { Different crank angles } \\
\left(-50^{\circ} \text { to } 50^{\circ}\right)\end{array}$ & - & $\begin{array}{l}\uparrow \text { by } 100 \mathrm{~g} / \mathrm{kWh} \\
\text { compared to } \\
\text { diesel fuel }\end{array}$ & & $\begin{array}{l}\text { (Kim and } \\
\text { Park, 2016) }\end{array}$ \\
\hline DEE & $10 \%$ vol. & $\begin{array}{l}\text { Different BMEP }(0.2 \text {, } \\
0.3,0.4,0.5,0.6,0.7 \\
\text { and } 0.8 \mathrm{MPa})\end{array}$ & - & $\begin{array}{l}\uparrow \text { compared to } \\
\text { diesel fuel. }\end{array}$ & - & $\begin{array}{l}\text { (Lee and } \\
\text { Kim, 2017) }\end{array}$ \\
\hline EEA & 5EEA & $\begin{array}{l}\text { Different loads }(0,20 \text {, } \\
40,60,80 \text { and } 100 \%)\end{array}$ & $\begin{array}{l}\uparrow \text { compared to diesel } \\
\text { fuel }\end{array}$ & $\begin{array}{l}\uparrow \text { compared to } \\
\text { diesel fuel }\end{array}$ & & $\begin{array}{l}\text { (Deepanraj } \\
\text { et al., 2011) }\end{array}$ \\
\hline
\end{tabular}

\subsection{Emission characteristics}

According to Yesilyurt et al. (Yesilyurt and Aydin, 2020), it is also found that the average HC, smoke, and NOx emissions exhausted by the engine fueled with ternary blends were $12.89 \%, 4.12 \%$, and $8.84 \%$, respectively lower than those of diesel fuel. The trend of CO emission exhibited an increase with the diesel fuel at higher DEE concentration through lower concentration at the maximum load recorded a slump up to $40.09 \%$ of CO emission. Incidentally, the $\mathrm{CO}_{2}$ also declined at high loads conditions. However, the combustion behaviours vaguely deteriorated when the CI engine run on all ternary blends. As a result, DEE can be considered as a favourable option for removing the major trouble in using cottonseed oil biodiesel. Further remarkable highlight demonstrated that the $10 \%$ (by vol.) of DEE in to blend is probably a potential technique for utilizing biodiesel/diesel blend efficiently in the CI engines without modifying. Additionally, in the study of More et al. (More et al., 2020), all tested fuels have an analogous trend at whole loading conditions and ratios of compression. According to the obtained results, the emissions of $\mathrm{CO}, \mathrm{HC}$, and $\mathrm{NOx}$ formatted by burning biodiesel-DEE-diesel blends in CI engine had the highest drop by $20.41 \%, 34.69 \%$, and $23.33 \%$ in comparison with diesel fuel at remarkable working conditions. Lower carbon content in the ternary 
blends caused the downward trend of $\mathrm{CO}_{2}$ emission. A notable comparison with diesel fuel showed $15.07 \%$, $3.45 \%$, and $14.70 \%$ minimization of $\mathrm{CO}, \mathrm{HC}$, and $\mathrm{NOx}$ emissions respectively, are provided by $0.8 \%$ concentration of DEE at CR15 in the ternary blend. More remarkably, in minimum content of DEE, luminous results are obtained by the A0.8B19.2 blend in characteristics of both performance and emission at CR15. Furthermore, Tree et al. (Tree and Cooley, 2001) compared the emissions (NOx and PM) consequent in the combustion of DEE with that of diesel fuel in the diesel engine. They explored that DEE creates less PM for a given level of NOx. A similar decline in the emissions of NOx and smoke by employing DEE-diesel blend fuel from a DI diesel engine with EGR was gained in the research of Anand et al. (Anand and Mahalakshmi, 2007) which was up to $15 \%$. A diesel engine equipped with EGR and fueled DEE-diesel blend was depicted as a feasible method for dropping the PM and NOx trade-off.

According to Paul et al. (Paul et al., 2015), the application of DEE in diesel fuel reduced the exhausted gases such as PM, CO, HC, and NOx (with 10\% DEE), nevertheless, $5 \%$ concentration of DEE (D95DEE5) shows a different trend in NOx emission. Emissions have significant fall (Figure 7), PM by $91 \%$, CO by $53 \%$, D80DEE10E10 in comparison to diesel. On the other hand, tests using DNBE additives added to diesel fuel to feed a 4-stroke, single-cylinder CI engine has yielded positive information on $\mathrm{HC}, \mathrm{CO}$ and $\mathrm{PM}$ emissions. At the same time, with the condition of increasing load, the improvement in emission characteristics is more obvious for DNBE additive blend fuel (Kerschgens et al., 2016). In a study on the emission characteristics of diesel engines using B20 biodiesel fuel with the addition of DEE additives up to $10 \%$, Yesilyurt et al. (Yesilyurt and Aydin, 2020) confirmed that NOx, smoke and HC emissions reduced by $8.8 \%, 4.1 \%$ and $12.9 \%$, respectively, compared to pure diesel fuel. Moreover, with the addition of $5 \% \mathrm{DEE}$ to $\mathrm{B} 20$ fuel, $\mathrm{CO}$ emissions are reduced by almost half compared to when using diesel fuel at the same test condition. Pochareddy et al. (Pochareddy et al., 2017) studied the emission characteristics of CI engines using fuel mixed by sapote seed oil methyl ester, 5\%DEE and diesel. It can be found that $\mathrm{CO}$, smoke and $\mathrm{HC}$ emissions are significantly reduced compared to pure diesel fuel, while exhaust gas temperature and NOx emissions increase. In a study by Chaudhary et al. (Chaudhary and Gakkhar, 2020), a direct injection diesel engine was operated at $1600 \mathrm{rpm}$ and full load, supplying waste cooking oil (WCO) blended with 5\%,10\% and 15\% vol. of DEE in $55 \%$ vol. of diesel, to evaluate the possibility of improving emission characteristics. The results and discussion of NOx emissions revealed that adding up to $15 \%$ DEE reduced NOx concentrations by about 4.5 times compared with WCO45 fuel (45\% WCO and 55\% diesel)(Balasubramanian et al., 2021c).

Geng et al. (Geng et al., 2017) experimented studied using DME-diesel fuel as a renewable alternative fuel for CI engines. The measured results proposed a longer injected delay timing, reductant in peak pressure in the cylinder, and shorter delay ignition which was different to those offered by using blended alcohol in diesel fuel. Moreover, PM tended to fall substantially with the growth of DME content. Moreover, Işık et. al (Işılk et al., 2020) researched generator diesel engines using blended fuels of diesel, biodiesel and DME additives such as B10DME10, B25DME25, B25, B100 and D2 (ULSD diesel) to evaluate combustion and emission characteristics (Tran et al., 2019). The addition of DME to biofuels has improved the viscosity of the blended fuel, resulting in improved combustion quality in the cylinders. In terms of emission characteristics, the addition of DME resulted in significant reductions in $\mathrm{CO}$ and $\mathrm{HC}$ emissions compared with B100 and D2 fuels at the loading modes, while NOx emissions increased slightly (Tran et al., 2021).
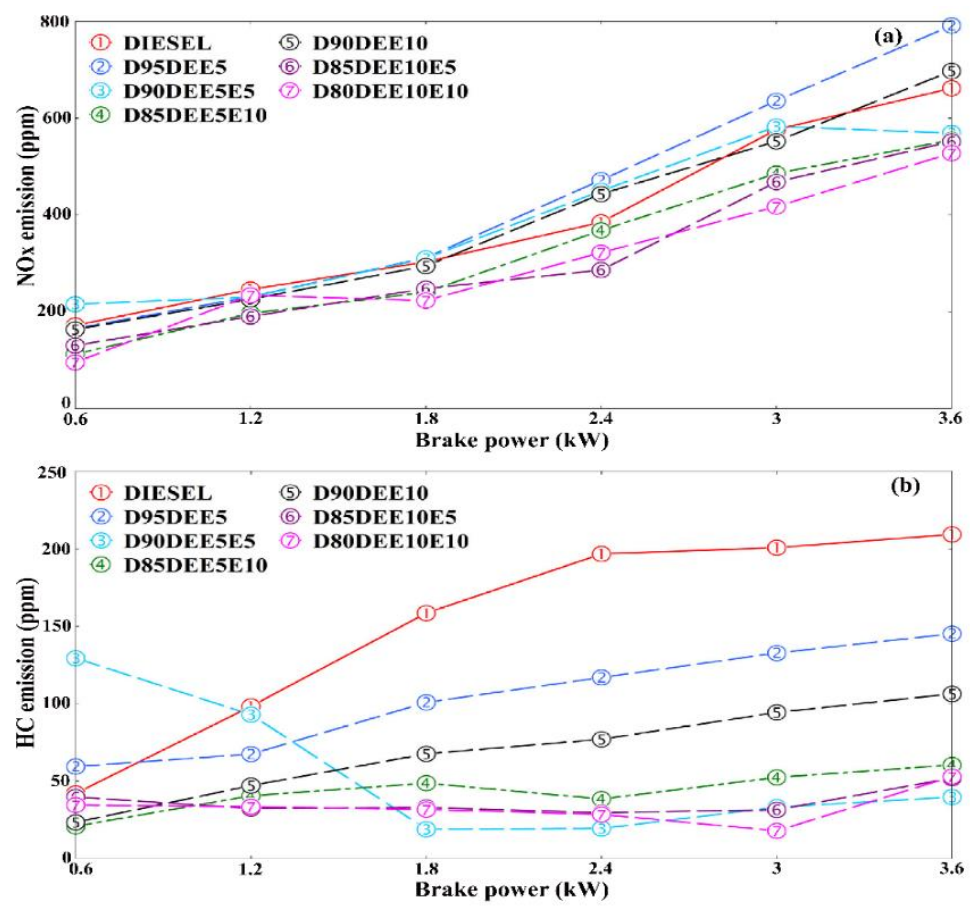

Fig. 6 The change of NOx and HC emission for modified blends with DEE (Paul et al., 2015) 
Adhinarayanan et al. (Adhinarayanan et al., 2020) analyzed the effects of using blended fuels such as D70L20D10 and D70L20DNBE10, which were produced by replacing $10 \%$ by vol. of LDPE oil in D70L30 blend fuel with 1-decanol and di-n-butyl ether, on the combustion and emission characteristics of 4-stroke, single-cylinder CI engines. The addition of DNBE improved brake thermal efficiency by $0.7 \%$ and $3.1 \%$ compared to diesel and D70L30 respectively (Figure 8). More interestingly, NOx emissions were found using the D70L20DNBE10 to be reduced by $5.7 \%$ compared to the D70L30. Smoke opacity is lower than D70L30 but higher than diesel fuel. The study of Miyamoto et al. (Miyamoto et al., 2000) concluded that the THC, NOx and CO emissions from CI engines decreased significantly with an increasing amount of DBE addition to conventional fuel and biodiesel. The above results can be derived from the abundant oxygen content of the DBE as well as the reduction of the Sauter Mean Diameter of the blended fuel to improve the injection characteristics of the biofuel (Guan et al., 2015).

In terms of 2 ethoxy-ethyl-acetate additives, the study of Wei et al. (Wei et al., 2017) on emission characteristics of direct injection, 4-stroke and single-cylinder diesel engines using diesel and EEA blend fuels including 5EEA, 10EEA and 15EEA, the role of EEA additive has been demonstrated. Research results have revealed that increasing the additive EEA in the fuel blend can reduce the concentration of pollutant emissions such as $\mathrm{HC}$ and $\mathrm{CO}$. The reason given by the author is due to the increase of atomic oxygen content from the EEA leading to more complete combustion. A study on the impact of EEA on emission characteristics by Sood et al. (Sood et al., 2014) showed that when the added EEA content was increased from $5 \%$ to $15 \%$, the smoke opacity decreased by $19 \%$, while the reduction in $\mathrm{CO}$ and $\mathrm{HC}$ emissions were also recorded $16 \%$ and $12 \%$ respectively in the loading modes. In testing with a direct injection CI engine with a compression ratio of $17: 1$ at five different loads and at a steady speed, the emission characteristics were improved with the contribution of EEA and NM additives in diesel fuel (Rao et al., 2020). Specifically, with D-EEA10-NM2, $\mathrm{HC}$ and smoke emissions recorded a decrease of about $48.3 \%$ and $62.3 \%$ respectively, while there is an increase of about $54.3 \%$ and $23.8 \%$ for $\mathrm{NOx}$ and $\mathrm{CO}$ emissions respectively in comparison with diesel fuel (Dung and Anh, 2020). Furthermore, NOx and CO emissions have also been reported to increase $55.2 \%$ and $14.7 \%$ respectively for D-EEA15-NM2 blended fuel compared to conventional fuel, while the improvement in $\mathrm{HC}$ and smoke emissions is said to be reduced by about $59 \%$ and $60 \%$ respectively.

According to Gnanamoorthi et al. (Gnanamoorthi and Murugan, 2019), the emission characteristics of a singlecylinder, 4-stroke CRDI diesel engine was revealed in a study using diesel-WPO blended fuels with the addition of DEE and MEA additives. Regarding CO emissions, the atomic oxygen content in the fuel reduced the emission concentrations in all WPO blend fuels. In comparison with pure diesel fuel, CO emissions of 50D40W10DEE, WPO and 50D40W10MEA decreased by $15.8 \%, 20.3 \%$ and $22.4 \%$ respectively. In addition, unburnt hydrocarbon (UHC) emissions have generally tended to increase when the fuel contains many aromatic compounds that are difficult to decompose by heat. As a result, the UHC content in the exhaust emission from engines using WPO was $23 \%$ higher in comparison with pure diesel fuel. More interestingly, when adding oxygen-rich additives to the WPO-diesel blend fuel, UHC emissions were reduced, specifically, the UHC of 50D40W10DEE and 50D40W10MEA was 5.7\% and $11.3 \%$ lower, respectively, than that of pure diesel fuel. Thus, the excess of atomic oxygen by the addition of DEE and MEA additives completely oxidized the remaining unsaturated hydrocarbons of WPO for cleaner combustion. In terms of NOx emissions, the presence of oxygen in WPO and its higher viscosity and density resulted in NOx emissions being about $23 \%$ higher than pure diesel fuel (Al-Tawaha et al., 2018). Even better, in comparison with pure diesel fuel, the DEE additive with higher oxygen concentration, higher cetane number and higher heat of vaporization promoted faster and shorter combustion. That has helped the NOx emission of D50W40DEE10 be recorded to be 5.3 $\%$ lower in comparison with pure traditional fuel. However, the higher density MEA additive led to a slight increase in NOx emissions compared with pure diesel fuel. Moreover, it is observed that the smoke opacity of WPO and D50W50 fuel is higher than that of diesel fuel (Thu and Anh, 2017). However, the addition of DEE and MEA additives stimulated complete combustion, resulting in a $7.1 \%$ and $15.5 \%$ reduction in smoke opacity of D50W40DEE10 and D50W40MEA10 respectively compared with diesel.
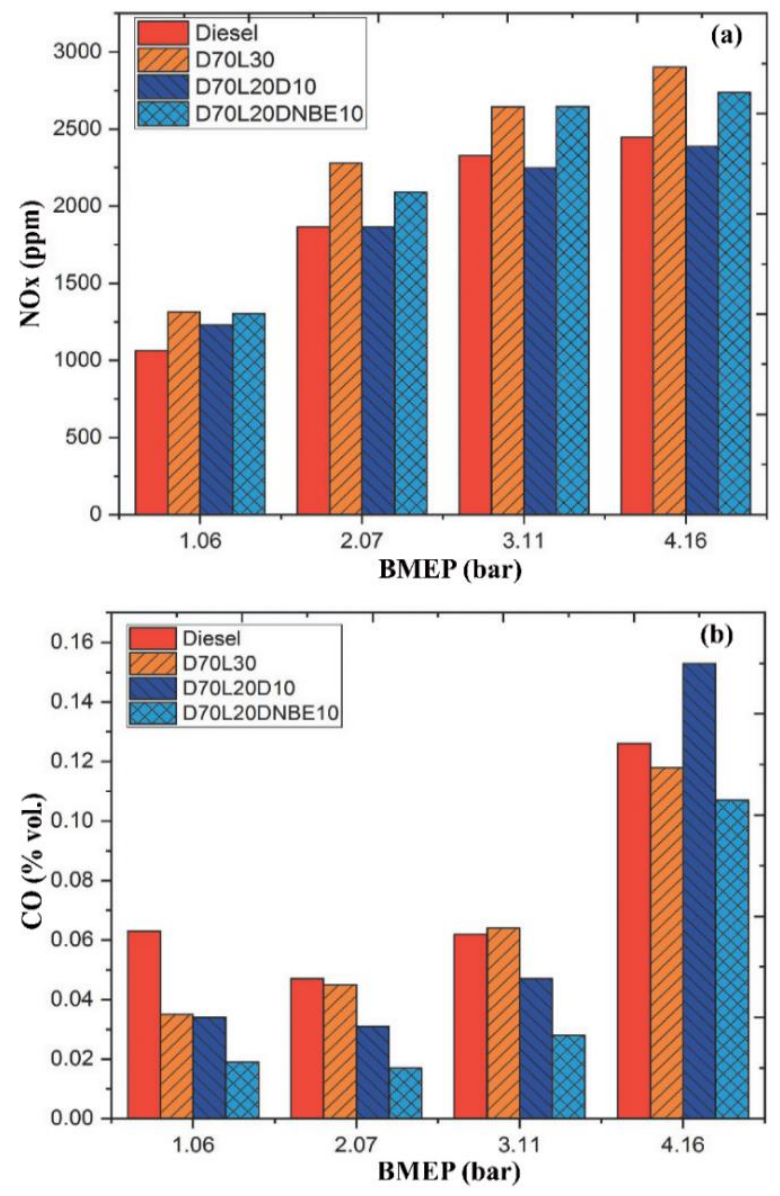

Fig. 8 The change of NOx (a) and CO (b) emission for blends with di-n-butyl ether (Adhinarayanan et al., 2020) 
In the marine field, diesel engines dominate almost completely because of their ability to provide a large capacity that is difficult to find a replacement engine. However, the emission problems from diesel engines with the environment are very worrisome. To reduce particulate, smoke and NOx emissions, the use of organic additives such as EGM to improve combustion quality and reduce environmental pollution has attracted many scholars (Chan, 2018). A study by Lin and co-workers (Lin and Huang, 2003) on 4-cylinder marine diesel engines with different rates of EGM addition to conventional fuels investigated the output parameters of $\mathrm{NOx}, \mathrm{CO}_{2}$ and $\mathrm{CO}$. The variable rate regime test data revealed that when the EGM addition rate was increased from $0 \%$ to $10 \%$, both $\mathrm{CO}_{2}$ and $\mathrm{CO}$ emissions decreased, while NOx emissions increased with the speed range below $1200 \mathrm{rpm}$, but turned to decrease at a higher speed range (Shoar et al., 2021).

A study by Yanxia et al. (Yanxia and Yongqi, 2007) was performed on a 4JB1 diesel engine using diesel fuel and the fuels were mixed with DMC and EGM to improve emission parameters from the engine. Indeed, at full load, using DMCEGM15 resulted in a maximum smoke emission reduction of approximately $59 \%$ compared to diesel fuel, however, test data also noted a role in smoke emission reduction of DMC was better than EGM. Regarding NOx emissions, there was little effect of the addition of the DMC-EGM surcharge on NOx emissions. Indeed, at a low load, the use of DMCEGM5 and
DMCEGM10 may have slightly reduced NOx emissions in the comparison with pure diesel, but with DMCEGM10 and DMCEGM15 a slight increase of NOx was recorded. Meanwhile, the mixed fuel of DMC, EGM and diesel caused NOx to increase slightly at higher loads. The addition of DMC and EGM additives to diesel fuel have both revealed sharp reductions in $\mathrm{CO}$ and $\mathrm{HC}$ emissions at higher loads. Thus, this has demonstrated the potential to use diesel fuel blended with DMC and EGM in controlling pollutant emissions (Vinh et al., 2018).

PODE is attracting a lot of interest from researchers about alternative fuels. Current pilot studies have been focusing on the addition of PODE additives to secondary or tertiary fuels to improve combustion quality and performance as well as reduce negative emissions effects due to the high oxygen content, high flash point and cetane number. A comparative evaluation study by Awad et al. (Awad et al., 2020) showed very significant effects of PODE on the emission characteristics of CI engines. The evolutions of changes in $\mathrm{HC}, \mathrm{CO}$ and NOx emissions are shown in Figure 9. The strongest reduction in $\mathrm{CO}$ and $\mathrm{HC}$ emissions was reported to be $20 \%$ with PODE (number of links 3-4) while that NOx emissions increase when PODE is involved (Wu et al., 2021)(Zhu et al., 2021).

Table 3 presents a summary of the prominent effects of ether additives on the emission characteristics (PM, CO, $\mathrm{HC}$ and NOx) of CI engines.

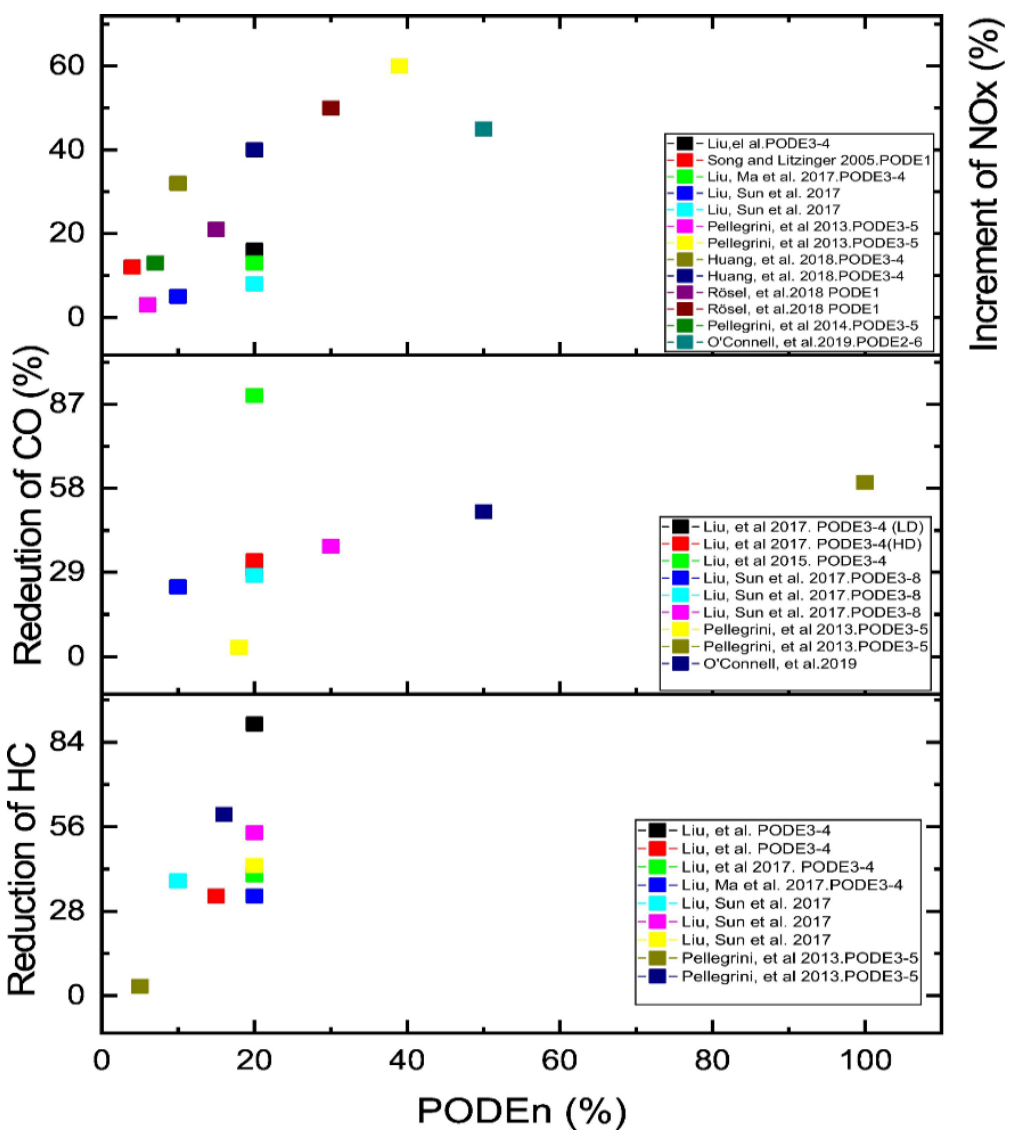

Fig. 9 Evolution of changes in HC, CO and NOx emissions according to the proportion of PODE participation in the adjusted fuel (Awad et al., 2020) 
Table 3

Summary of engine emission characteristics using ethers and esters compound additives

\begin{tabular}{|c|c|c|c|c|c|c|c|}
\hline Additive & Concentration & $\begin{array}{c}\text { Test } \\
\text { condition }\end{array}$ & NOx & $\mathrm{CO}$ & HC & PM/Soot & Ref. \\
\hline \multirow[t]{5}{*}{ DEE } & $5 \% \mathrm{DEE}$ & $\begin{array}{l}\text { Different } \\
\text { loads }(20,40, \\
60,80 \text { and }\end{array}$ & - & $\begin{array}{c}\downarrow \text { compared to } \\
\text { diesel fuel and } \\
10 \% \mathrm{DEE}\end{array}$ & - & $\begin{array}{l}\text { (smoke) } \downarrow \\
\text { compared to } \\
\text { diesel fuel }\end{array}$ & $\begin{array}{l}\text { (Mohanan et } \\
\text { al., 2003) }\end{array}$ \\
\hline & $10 \% \mathrm{DEE}$ & $\begin{array}{l}100 \%) \\
\text { Injection }\end{array}$ & - & $\begin{array}{c}\downarrow \text { compared to } \\
\text { diesel fuel }\end{array}$ & - & $\begin{array}{l}\uparrow \text { compared to } \\
\text { diesel fuel }\end{array}$ & \\
\hline & $15 \% \mathrm{DEE}$ & $\begin{array}{l}\text { timing at } 27^{\circ} \\
\text { BTDC } \\
\text { Engine }\end{array}$ & - & $\begin{array}{c}\uparrow \text { compared to } \\
\text { diesel fuel }\end{array}$ & - & $\begin{array}{l}\uparrow \text { compared to } \\
\text { diesel fuel } 10 \% \\
\text { DEE }\end{array}$ & \\
\hline & $20 \% \mathrm{DEE}$ & $\begin{array}{l}\text { speed at } \\
1500 \mathrm{rpm}\end{array}$ & - & $\begin{array}{c}\uparrow \text { compared to } \\
\text { diesel fuel and } \\
15 \% \mathrm{DEE}\end{array}$ & - & $\begin{array}{l}\uparrow \text { compared to } \\
\text { diesel fuel and } \\
15 \% \text { DEE }\end{array}$ & \\
\hline & $25 \% \mathrm{DEE}$ & & - & $\begin{array}{c}\uparrow \text { compared to } \\
\text { diesel fuel and } \\
20 \% \mathrm{DEE}\end{array}$ & - & $\begin{array}{l}\uparrow \text { compared to } \\
\text { diesel fuel and } \\
20 \% \text { DEE }\end{array}$ & \\
\hline \multirow[t]{3}{*}{ DEE } & B4 (4\%) & $\begin{array}{l}\text { Different } \\
\text { loads }(25,50, \\
75 \text { and } \\
100 \%)\end{array}$ & $\begin{array}{l}\uparrow \text { compared to } \\
\text { diesel fuel but } \\
\text { lower than } \\
\text { other blends } \\
\uparrow \text { compared to } \\
\text { diesel fuel }\end{array}$ & $\begin{array}{l}\downarrow \text { compared to } \\
\text { diesel fuel but } \\
\text { higher than } \\
\text { other blends } \\
\downarrow \text { compared to } \\
\text { diesel fuel }\end{array}$ & $\begin{array}{l}\downarrow \text { compared to } \\
\text { diesel fuel but } \\
\text { higher than } \\
\text { other blends } \\
\downarrow \text { compared to } \\
\text { diesel fuel }\end{array}$ & $\begin{array}{l}\downarrow \text { compared to } \\
\text { diesel fuel but } \\
\text { higher than } \\
\text { other blends } \\
\downarrow \text { compared to } \\
\text { diesel fuel, } \\
\text { lower than B4 }\end{array}$ & $\begin{array}{l}\text { (Kapilan } \\
\text { al., 2008) }\end{array}$ \\
\hline & B6 (6\%) & & $\begin{array}{l}\uparrow \text { compared to } \\
\text { diesel fuel }\end{array}$ & $\begin{array}{l}\downarrow \text { compared to } \\
\text { diesel fuel }\end{array}$ & $\begin{array}{l}\downarrow \text { compared to } \\
\text { diesel fuel }\end{array}$ & $\begin{array}{l}\downarrow \text { compared to } \\
\text { diesel fuel, } \\
\text { lower than B5 }\end{array}$ & \\
\hline & B7 (7\%) & & $\begin{array}{l}\uparrow \text { compared to } \\
\text { diesel fuel }\end{array}$ & $\begin{array}{l}\downarrow \text { compared to } \\
\text { diesel fuel }\end{array}$ & $\begin{array}{l}\downarrow \text { compared to } \\
\text { diesel fuel }\end{array}$ & $\begin{array}{l}\downarrow \text { compared to } \\
\text { diesel fuel but } \\
\text { lower than } \\
\text { other blends }\end{array}$ & \\
\hline \multirow[t]{2}{*}{ DME } & $14 \%$ vol. & $\begin{array}{l}\text { Different } \\
\text { EGR rates } \\
(9,18 \text { and }\end{array}$ & $\begin{array}{l}\downarrow \text { compared to } \\
\text { diesel fuel }\end{array}$ & $\begin{array}{l}\uparrow \text { compared to } \\
\text { diesel fuel }\end{array}$ & $\begin{array}{l}\uparrow \text { compared to } \\
\text { diesel fuel }\end{array}$ & $\begin{array}{l}\text { (smoke) } \downarrow \\
\text { compared to } \\
\text { diesel fuel }\end{array}$ & $\begin{array}{l}\text { (Zhao et al., } \\
2014)\end{array}$ \\
\hline & $30 \%$ vol. & $\begin{array}{l}27 \%) \\
\text { Different } \\
\text { BMEP (0.25 } \\
\text { and } 0.5 \\
\text { MPa) }\end{array}$ & $\begin{array}{l}\downarrow \text { compared to } \\
\text { diesel fuel and } \\
14 \% \text { DME }\end{array}$ & $\begin{array}{l}\uparrow \text { compared to } \\
\text { diesel fuel and } \\
14 \% \mathrm{DME}\end{array}$ & $\begin{array}{l}\uparrow \text { compared to } \\
\text { diesel fuel and } \\
14 \% \mathrm{DME}\end{array}$ & $\begin{array}{l}\text { (smoke) } \downarrow \\
\text { compared to } \\
\text { diesel fuel and } \\
14 \% \text { DME }\end{array}$ & \\
\hline \multirow[t]{6}{*}{ DEE } & DE2D & $\begin{array}{l}\text { Different } \\
\text { BMEP }(0.1, \\
0.2,0.3,0.4 \\
\text { and } 0.5\end{array}$ & $\begin{array}{l}\downarrow \text { compared to } \\
\text { diesel fuel but } \\
\uparrow \text { with BMEP } \\
\text { over } 0.3 \mathrm{Mpa}\end{array}$ & $\begin{array}{l}\text { No change } \\
\text { compared to } \\
\text { diesel fuel }\end{array}$ & $\begin{array}{l}\uparrow \text { compared to } \\
\text { diesel fuel, only } \\
\downarrow \text { with BMEP } \\
\text { under } 0.1 \mathrm{Mpa}\end{array}$ & $\begin{array}{l}\downarrow \text { compared to } \\
\text { diesel fuel }\end{array}$ & $\begin{array}{l}\text { (Patil and } \\
\text { Thipse, 2015) }\end{array}$ \\
\hline & DE5D & $\mathrm{MPa})$ & $\begin{array}{l}\downarrow \text { compared to } \\
\text { diesel fuel }\end{array}$ & $\begin{array}{l}\downarrow \text { compared to } \\
\text { diesel fuel }\end{array}$ & $\begin{array}{l}\uparrow \text { compared to } \\
\text { diesel fuel, only } \\
\downarrow \text { with BMEP } \\
\text { under } 0.1 \mathrm{Mpa}\end{array}$ & $\begin{array}{l}\downarrow \text { compared to } \\
\text { diesel fuel }\end{array}$ & \\
\hline & DE8D & & $\begin{array}{l}\downarrow \text { compared to } \\
\text { diesel fuel }\end{array}$ & $\begin{array}{l}\text { No change } \\
\text { compared to } \\
\text { diesel fuel }\end{array}$ & $\begin{array}{l}\uparrow \text { compared to } \\
\text { diesel fuel }\end{array}$ & $\begin{array}{l}\downarrow \text { compared to } \\
\text { diesel fuel }\end{array}$ & \\
\hline & DE10D & & $\begin{array}{l}\downarrow \text { compared to } \\
\text { diesel fuel }\end{array}$ & $\begin{array}{l}\downarrow \text { compared to } \\
\text { diesel fuel but } \\
\uparrow \text { with BMEP } \\
\text { of } 0.25 \text { to } 0.4 \\
\text { Mpa }\end{array}$ & $\begin{array}{l}\uparrow \text { compared to } \\
\text { diesel fuel }\end{array}$ & $\begin{array}{l}\downarrow \text { compared to } \\
\text { diesel fuel }\end{array}$ & \\
\hline & DE15D & & $\begin{array}{l}\downarrow \text { compared to } \\
\text { diesel fuel }\end{array}$ & $\begin{array}{l}\downarrow \text { compared to } \\
\text { diesel fuel }\end{array}$ & $\begin{array}{l}\uparrow \text { compared to } \\
\text { diesel fuel, only } \\
\downarrow \text { with BMEP } \\
\text { under } 0.1 \mathrm{Mpa}\end{array}$ & $\begin{array}{l}\downarrow \text { compared to } \\
\text { diesel fuel }\end{array}$ & \\
\hline & DE20D & & $\begin{array}{l}\downarrow \text { compared to } \\
\text { diesel fuel and } \\
\text { lower than } \\
\text { other blends }\end{array}$ & $\begin{array}{l}\downarrow \text { compared to } \\
\text { diesel fuel }\end{array}$ & $\begin{array}{l}\uparrow \text { compared to } \\
\text { diesel fuel, only } \\
\downarrow \text { with BMEP } \\
\text { under } 0.1 \mathrm{Mpa}\end{array}$ & $\begin{array}{l}\downarrow \text { compared to } \\
\text { diesel fuel but } \\
\uparrow \text { with BMEP } \\
\text { over } 0.35 \mathrm{Mpa}\end{array}$ & \\
\hline DME & $\begin{array}{l}\text { Equivalence } \\
\text { ratio from } 0.4 \text { to } \\
0.7\end{array}$ & $\begin{array}{l}\text { Different } \\
\text { crank angles } \\
\left(-50^{\circ} \text { to } 50^{\circ}\right)\end{array}$ & $\begin{array}{l}\downarrow \text { compared to } \\
\text { diesel fuel }\end{array}$ & - & - & $\begin{array}{l}\downarrow \text { compared to } \\
\text { diesel fuel }\end{array}$ & $\begin{array}{l}\text { (Kim and } \\
\text { Park, 2016) }\end{array}$ \\
\hline DEE & $\begin{array}{l}\text { DEE10 (10\% } \\
\text { vol.) }\end{array}$ & $\begin{array}{l}\text { Different } \\
\text { BMEP }(0.2, \\
0.3,0.4,0.5 \text {, } \\
0.6,0.7 \text { and } \\
0.8 \mathrm{MPa})\end{array}$ & $\begin{array}{l}\uparrow \text { compared to } \\
\text { diesel fuel }\end{array}$ & $\begin{array}{l}\downarrow \text { compared to } \\
\text { diesel fuel }\end{array}$ & $\begin{array}{l}\downarrow \text { compared to } \\
\text { diesel fuel }\end{array}$ & $\begin{array}{l}\downarrow \text { compared to } \\
\text { diesel fuel }\end{array}$ & $\begin{array}{l}\text { (Lee and Kim, } \\
\text { 2017) }\end{array}$ \\
\hline
\end{tabular}




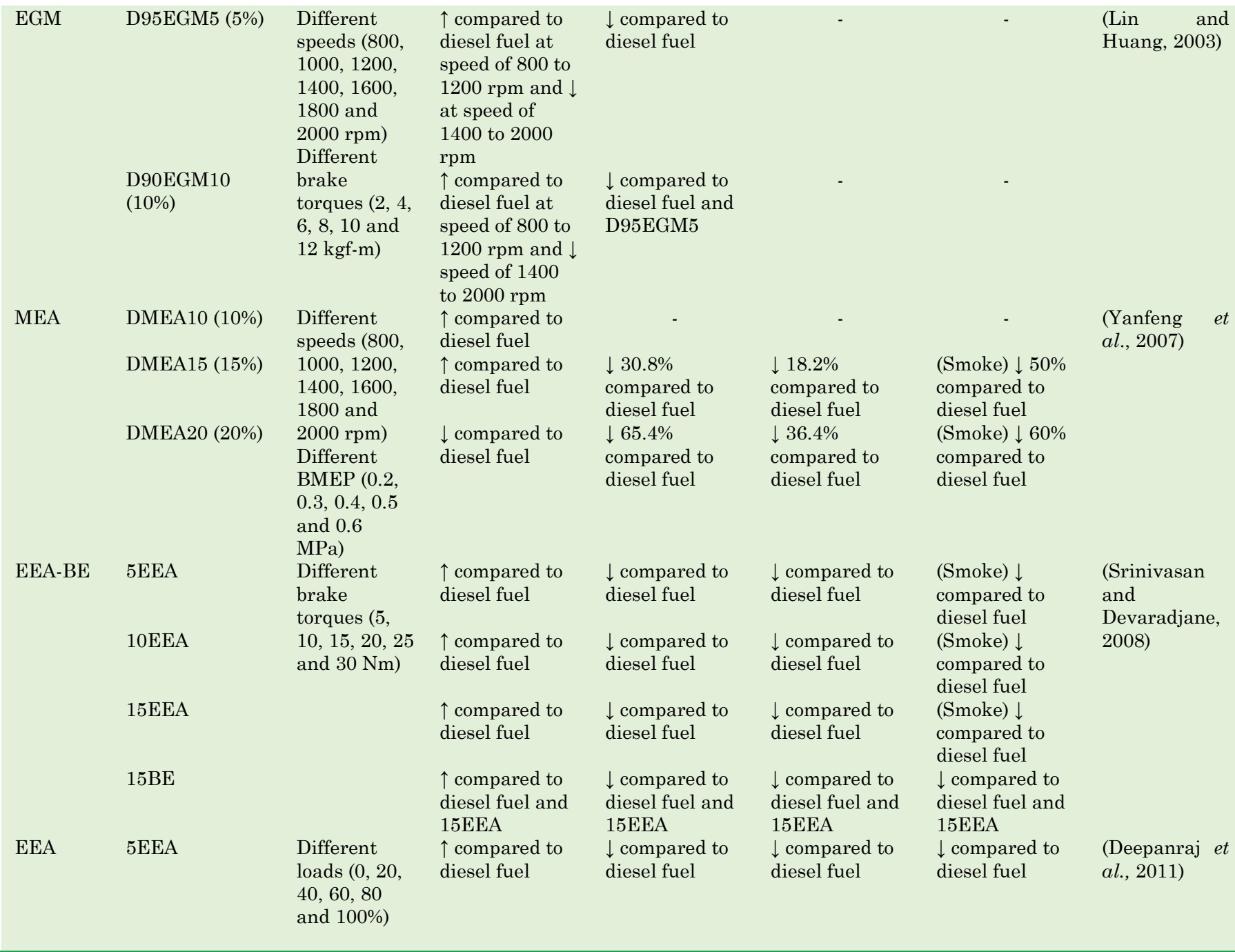

\section{Challenges and future directions}

Transparent and long-term strategies for sustainable energy use and management based on renewable energy sources (Balasubramanian et al., 2021b) and integration of Internet of Things technologies (Chau et al., 2021) are seen as the brightest solutions to overcome fossil energy depletion and global environmental pollution. More importantly, the sustainable energy development policies of governments (Xuan and Viet, 2021)(Dong et al., 2021) will be the essential key for research on renewable and sustainable energy to be widely deployed in production and society. Organic additives are emerging with many promising candidates such as alcohol, ether, ester, DMF, etc. The addition of such additives to biodiesel has contributed significantly to improving combustion quality and reducing emissions from CI engines (Devarajan et al., 2019). In particular, recently, furan-based additives have attracted more attention because of their huge production potential from biomass as well as their compatibility with conventional fuels and engines (Ong et al., 2020). In the future, the combination of many different additives to form tertiary and quaternary fuel will promote synergistic effects in improving engine performance and reduce negative environmental impacts (Nayaka et al., 2021)(Gonca and Genc, 2021). In addition, the use of carbon or metal nanoparticle additives (Hoang, 2021)(Murugesan et al., 2021), as well as the development of advanced injection techniques (Hoang, 2020) are also considered an alternative or combined option to overcome the disadvantages of biofuels. However, the economic, environmental and engine durability studies when using organic additives also need to be considered more thoroughly (Anh and Anh, 2019). More importantly, the strategies using electric vehicles (Nguyen et al., 2020), development of novel material for energy storage and energy management (Subramanian et al., 2021) should be considerably focused. In addition, the trends of biofuel production integrated with the circular economy (Atabani et al., 2021), as well as the support of the policy of government in renewable energy (Pandey et al., 2021) should be conducted in order to promote the biofuel production progress as fast as possible, and still meet the critical requirement relating to minimum secondary pollution.

\section{Conclusions}

Organic or oxygenated additives have been introduced to improve combustion in CI engines. This work specifically addressed ether additives, which are claiming 
great potential in the goal of sustainable renewable biofuels. Based on recent relevant literature, an integrated assessment of the properties of ether additives added into base fuels was discussed in this study to clarify their role in combustion behaviour and emissions formation.

The results showed that, with higher concentrations of oxygen in the composition of ethers, the added atomic oxygen was richer in the blended fuel, resulting in improved overall combustion efficiency. The presence of fairly high oxygen content in MEA, DME, EXEE, etc. promoted complete combustion, resulting in reduced PM, $\mathrm{HC}$ and $\mathrm{CO}$ emissions. A rather prominent advantage of using ether additives in biofuels is that the maximum combustion temperature has been reduced and simultaneous combustion leads to a reduction in NOx emissions formed in most of the studies. However, the energy content of ether additives is lower than that of diesel and biodiesel fuels, resulting in lower heat generated when oxidizing the fuel mixture in the combustion chamber. As a result, brake specific fuel consumption may be slightly reduced compared to conventional fuel.

Finally, organic additives are playing a very important role in improving the properties of diesel and biodiesel fuels to improve combustion efficiency and minimize negative impacts on the environment. However, to optimize the outstanding properties of ether additives in studies of their effects on combustion, emission formation and engine characteristics are still limited. Therefore, optimization studies on blending ratio, type of organic additive, operational modes, and type of biofuel need to be expanded in the future.

\section{References}

Adhinarayanan, R., Ramakrishnan, A., Kaliyaperumal, G., De Poures, M., Babu, R.K., Dillikannan, D., 2020. Comparative analysis on the effect of 1-decanol and di-nbutyl ether as additive with diesel/LDPE blends in compression ignition engine. Energy Sources, Part A Recover. Util. Environ. Eff. 1-18.

Aghbashlo, M., Rastegari, H., Ghaziaskar, H.S., HosseinzadehBandbafha, H., Nadian, M.H., Shafizadeh, A., Lam, S.S., Tabatabaei, M., 2022. Exergy, economic, and environmental assessment of ethanol dehydration to diesel fuel additive diethyl ether. Fuel 308, 121918.

Al-Tawaha, A., Pham, M.T., Le, A.T., Dong, V.H., Le, V.V., 2018. Measurement and prediction of the density and viscosity of biodiesel blends. Int. J. Technol. 5, 1015-1026.

Al-Tawaha, A.R.M.S., Tran, Q.V., Pham, V.V., Nguyen, X.P., 2019. Comparative analysis on performance and emission characteristics of an in-Vietnam popular 4-stroke motorcycle engine running on biogasoline and mineral gasoline. Renew. Energy Focus 28, 47-55. https://doi.org/10.1016/j.ref.2018.11.001

Anand, R., Mahalakshmi, N. V., 2007. Simultaneous reduction of NOx and smoke from a direct-injection diesel engine with exhaust gas recirculation and diethyl ether. Proc. Inst. Mech. Eng. Part D J. Automob. Eng. https://doi.org/10.1243/09544070JAUTO258

Anh, H., 2018. Waste heat recovery from diesel engines based on Organic Rankine Cycle. Appl. Energy 231, 138-166. https://doi.org/10.1016/j.apenergy.2018.09.022

Anh, L.T., Anh, H.T., 2019. Trilateral correlation of spray characteristics, combustion parameters, and deposit formation in the injector hole of a diesel engine running on preheated Jatropha oil and fossil diesel fuel. Biofuel Res. J. 6, 909-919. https://doi.org/10.18331/BRJ2019.6.1.2

Anh, T.H., 2018. Prediction of the density and viscosity of biodiesel and the influence of biodiesel properties on a diesel engine fuel supply system. J. Mar. Eng. Technol.

Arslan, E., Kahraman, N., 2021. The effects of hydrogen enriched natural gas under different engine loads in a diesel engine. $\begin{array}{llll}\text { Int. } & \text { J. Hydrogen }\end{array}$ https://doi.org/10.1016/j.ijhydene.2021.09.016

Atabani AE, Tyagi VK, Fongaro G, et al (2021) Integrated biorefineries, circular bio-economy, and valorization of organic waste streams with respect to bio-products. https://doi.org/10.1007/s13399-021-02017-4.

Atarod, P., Khlaife, E., Aghbashlo, M., Tabatabaei, M., Hoang, A.T., Mobli, H., Nadian, M.H., Hosseinzadeh-Bandbafha, H., Mohammadi, P., Shojaei, T.R., 2021. Soft computingbased modeling and emission control/reduction of a diesel engine fueled with carbon nanoparticle-dosed water/diesel emulsion fuel. J. Hazard. Mater. 407, 124369.

Awad, O.I., Ma, X., Kamil, M., Ali, O.M., Ma, Y., Shuai, S., 2020. Overview of polyoxymethylene dimethyl ether additive as an eco-friendly fuel for an internal combustion engine: Current application and environmental impacts. Sci. Total Environ. $715, \quad 136849$. https://doi.org/https://doi.org/10.1016/j.scitotenv.2020.1368 49

Aydin, S.G., Polat, O., Ozgen, A., Turali, E., 2020. Calculated Optimized Structure and Geometric Analysis of Oxygenated Fuel Additives: Alcohols and Ethers. Eng. Technol. Appl. Sci. Res. 10, 5632-5636.

Balasubramanian, D., Hoang, A.T., Venugopal, I.P., Shanmugam, A., Gao, J., Wongwuttanasatian, T., 2021a. Numerical and experimental evaluation on the pooled effect of waste cooking oil biodiesel/diesel blends and exhaust gas recirculation in a twin-cylinder diesel engine. Fuel 287, 119815. https://doi.org/10.1016/j.fuel.2020.119815

Balasubramanian, D., Nguyen, H.P., Huy, L.P.Q., Pham, V.V., Nguyen, X.P., Hoang, A.T., 2021b. Application of the Internet of Things in 3E factor (Efficiency, Economy, and Environment) factor-based energy management as smart and sustainable strategy. Energy Sources, Part A Recover. Util. Environ. https://doi.org/10.1080/15567036.2021.1954110.

Balasubramanian, D., Papla Venugopal, I., Shanmugam, A., Gao, J., Wongwuttanasatian, T., 2021c. Numerical and experimental evaluation on the pooled effect of waste cooking oil biodiesel/diesel blends and exhaust gas recirculation in a twin-cylinder diesel engine. Fuel 287, 119815. https://doi.org/10.1016/j.fuel.2020.119815

Barro, C., Parravicini, M., Boulouchos, K., 2019. Neat polyoxymethylene dimethyl ether in a diesel engine; part 1: Detailed combustion analysis. Fuel 256, 115892. https://doi.org/https://doi.org/10.1016/j.fuel.2019.115892

Bauer, M.C., Kruse, A., 2019. The use of dimethyl ether as an organic extraction solvent for biomass applications in future biorefineries: A user-oriented review. Fuel 254, 115703.

Bragadeshwaran, A., Kasianantham, N., Ballusamy, S., Tarun, K.R., Dharmaraj, A.P., Kaisan, M.U., 2018. Experimental study of methyl tert-butyl ether as an oxygenated additive in diesel and Calophyllum inophyllum methyl ester blended fuel in CI engine. Environ. Sci. Pollut. Res. 25, 33573-33590. https://doi.org/10.1007/s11356-018-3318-y

Bui, T.M.T., Nguyen Thi, T.X., Vo, A.V., Bui, V.G., Nižetić, S., 2021. Hydrogen-Enriched Biogas Premixed Charge Combustion and Emissions in Direct Injection and Indirect Injection Diesel Dual Fueled Engines: A Comparative Study. J. Energy Resour. Technol. 143. https://doi.org/10.1115/1.4051574

Bui, T.T., Luu, H.Q., Konur, O., Huu, T., Pham, M.T., 2020. A review on ignition delay times of 2,5-Dimethylfuran. Energy Sources, Part A Recover. Util. Environ. Eff. 1-16. https://doi.org/10.1080/15567036.2020.1860163 
Bui, V.G., Bui, T.M.T., Hoang, A.T., Nižetić, S., Sakthivel, R., Engel, D., Hadiyanto, H., 2021. Energy storage onboard zero-emission two-wheelers: Challenges and technical solutions. Sustain. Energy Technol. Assessments 47, 101435.

Cao, D.N., Luu, H.Q., Bui, V.G., Tran, T.T.H., 2020. Effects of injection pressure on the NOx and PM emission control of diesel engine: A review under the aspect of PCCI combustion condition. Energy Sources, Part A Recover. Util. Environ. Eff. 1-18. https://doi.org/10.1080/15567036.2020.1754531.

Chaichana, E., Boonsinvarothai, N., Chitpong, N., Jongsomjit, B., 2019. Catalytic dehydration of ethanol to ethylene and diethyl ether over alumina catalysts containing different phases with boron modification. J. Porous Mater. 26, 599610.

Chan, D.N., 2018. Properties of DMF-fossil gasoline RON95 blends in the consideration as the alternative fuel. Int. J. Adv. Sci. Eng. Inf. Technol. 8, 2555-2560.

Charoensuppanimit, P., Chaiapha, B., Assabumrungrat, S., Jongsomjit, B., 2021. Incorporation of diethyl ether production to existing bioethanol process: Techno-economic analysis. J. Clean. Prod. 327, 129438. https://doi.org/https://doi.org/10.1016/j.jclepro.2021.12943 8.

Chau MQ, Le V V, Al-Tawaha A, Pham V V (2020) A simulation research of heat transfers and chemical reactions in the fuel steam reformer using exhaust gas energy from motorcycle engine. J Mech Eng Res Dev 43:89-102.

Chau, M.Q., Nguyen, X.P., Huynh, T.T., Chu, V.D., Le, T.H., Nguyen, T.P., Nguyen, D.T., 2021. Prospects of application of IoT-based advanced technologies in remanufacturing process towards sustainable development and energyefficient use. Energy Sources, Part A Recover. Util. Environ. Eff. 1-25. https://doi.org/10.1080/15567036.2021.1994057.

Chaudhary, V., Gakkhar, R.P., 2020. Influence of DEE on Entropy Generation and Emission Characteristics of DI Diesel Engine Fuelled with WCO Biodiesel, in: Alternative Fuels and Their Utilization Strategies in Internal Combustion Engines. Springer, pp. 167-178.

Chen, W.-H., Nižetić, S., Sirohi, R., Huang, Z., Luque, R., M.Papadopoulos, A., Sakthivel, R., Phuong Nguyen, X., 2021a. Liquid hot water as sustainable biomass pretreatment technique for bioenergy production: A

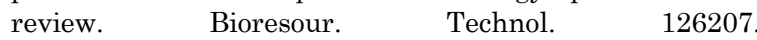
https://doi.org/10.1016/j.biortech.2021.126207

Chen, W.-H., Wang, C.-M., Huat Saw, L., Bandala, A.A., 2021b. Performance evaluation and improvement of thermoelectric generators (TEG): Fin installation and compromise optimization. Energy Convers. Manag. 250, 114858. https://doi.org/10.1016/j.enconman.2021.114858

Cheng, C.K., Ong, H.C., Fattah, I.M.R., Chong, C.T., Sakthivel, R., Ok, Y.S., 2021. Progress on the lignocellulosic biomass pyrolysis for biofuel production toward environmental sustainability. Fuel Process. Technol. 223, 106997. https://doi.org/10.1016/j.fuproc.2021.106997

Chong, C.T., Nizetic, S., Ong, H.C., Atabani, A.E., Pham, V.V., 2021. Acid-based lignocellulosic biomass biorefinery for bioenergy production: Advantages, application constraints, and perspectives. J. Environ. Manage. 296, 113194. https://doi.org/10.1016/j.jenvman.2021.113194

Das, D., Kumar, A., Yadav, A., 2018. Evaluation of performance, emission and combustion characteristics of a CI engine fueled with karanja biodiesel and diethyl ether blends. Biofuels 9, 89-94.

de França Lopes, G., Bonfim-Rocha, L., de Matos Jorge, L.M., Paraíso, P.R., 2020. Dimethyl ether production from sugarcane vinasse: modeling and simulation for a technoeconomic assessment. Bioenergy Res. 1-14.

de Menezes, E.W., da Silva, R., Cataluna, R., Ortega, R.J.C., 2006. Effect of ethers and ether/ethanol additives on the physicochemical properties of diesel fuel and on engine tests. Fuel 85, 815-822.

Deepanraj, B., Lawrence, P., Kannan, M., Nadanakumar, V., Santhanakrishnan, S., Senthil, R., 2011. Study on performance and emission characteristics of a compression ignition engine fueled with diesel-2 ethoxy ethyl acetate blends. Engineering 2011

Deutz, S., Bongartz, D., Heuser, B., Kätelhön, A., Langenhorst, L.S., Omari, A., Walters, M., Klankermayer, J., Leitner, W., Mitsos, A., 2018. Cleaner production of cleaner fuels: wind-to-wheel-environmental assessment of CO 2-based oxymethylene ether as a drop-in fuel. Energy Environ. Sci. 11, 331-343.

Devaraj, J., Robinson, Y., Ganapathi, P., 2015. Experimental investigation of performance, emission and combustion characteristics of waste plastic pyrolysis oil blended with diethyl ether used as fuel for diesel engine. Energy 85, 304309.

Devarajan, Y., Munuswamy, D., Nagappan, B., Subbiah, G., 2019. Experimental assessment of performance and exhaust emission characteristics of a diesel engine fuelled with Punnai biodiesel/butanol fuel blends. Pet. Sci. 16, 14711478. https://doi.org/10.1007/s12182-019-00361-9

Dong, V.H., Nguyen, X.P., Le, N.D., Pham, V.V., Huynh, T.T., 2021. Mission, challenges, and prospects of renewable energy development in Vietnam. Energy Sources, Part A Recover. Util. Environ. Eff. 1-13. https://doi.org/10.1080/15567036.2021.1965264

Dung, V.T., Anh, H.T., 2020. Experimental Analysis on the Ultrasound-based Mixing Technique Applied to Ultra-low Sulphur Diesel and Bio-oils 9, 307-313.

Engel, D., Nguyen, X.P., Ölçer, A.I., Pham, V.V., Nayak, S.K., 2021. Biomass-derived 2,5-dimethylfuran as a promising alternative fuel: An application review on the compression and spark ignition engine. Fuel Process. Technol. 214, 106687. https://doi.org/10.1016/j.fuproc.2020.106687

Fayyazbakhsh, A., Pirouzfar, V., 2017. Comprehensive overview on diesel additives to reduce emissions, enhance fuel properties and improve engine performance. Renew. Sustain. Energy Rev. https://doi.org/10.1016/j.rser.2017.03.046

Fu, W., Li, F., Meng, K., Liu, Y., Shi, W., Lin, Q., 2019. Experiment and analysis of spray characteristics of biodiesel blending with di-n-butyl ether in a direct injection combustion chamber. Energy 185, 77-89.

Geng, P., Cao, E., Tan, Q., Wei, L., 2017. Effects of alternative fuels on the combustion characteristics and emission products from diesel engines: A review. Renew. Sustain. Energy Rev. https://doi.org/10.1016/j.rser.2016.12.080

Gnanamoorthi, V., Murugan, M., 2019. Effect of DEE and MEA as additives on a CRDI diesel engine fueled with waste plastic oil blend. Energy Sources, Part A Recover. Util. Environ. Eff. 1-16. https://doi.org/10.1080/15567036.2019.1657206

Gonca, G., Genc, I., 2021. Effects of ternary mixtures of propanebutane-hydrogen and different liquid fuels on the performance specifications of a spark ignition engine. Energy Sources, Part A Recover. Util. Environ. Eff. 1-18.

Guan, L., Tang, C., Yang, K., Mo, J., Huang, Z., 2015. Effect of din-butyl ether blending with soybean-biodiesel on spray and atomization characteristics in a common-rail fuel injection system. Fuel 140, 116-125.

Hadiyanto, H., Aini, A.P., Widayat, W., Kusmiyati, K., Budiman, A., Rosyadi, A., 2020. Multi-Feedstock Biodiesel Production from Esterification of Calophyllum inophyllum Oil, Castor Oil, Palm Oil, and Waste Cooking Oil. Int. J. Renew. Energy Dev. 9.

Hidzir, N.S., Som, A.S., Abdullah, Z., 2014. Ethanol production via direct hydration of ethylene: A review, in: International Conference on Global Sustainability and Chemical Engineering (ICGSE).

Hoang, A.T., 2021. Combustion behavior, performance and 
emission characteristics of diesel engine fuelled with biodiesel containing cerium oxide nanoparticles: A review. Fuel Process. Technol. 218, 106840.

Hoang AT (2020) Applicability of fuel injection techniques for modern diesel engines. 020018. https://doi.org/10.1063/5.0000133

Hoang, A.T., 2019. Experimental study on spray and emission characteristics of a diesel engine fueled with preheated biooils and diesel fuel. Energy 171, 795-808. https://doi.org/10.1016/j.energy.2019.01.076

Hoang, A.T., 2018. Waste heat recovery from diesel engines based on Organic Rankine Cycle. Appl. Energy 231, 138-166.

Höök, M., Tang, X., 2013. Depletion of fossil fuels and anthropogenic climate change-A review. Energy Policy $52,797-809$.

Huynh, T.T., Nguyen, X.P., Le, A.T., Pham, V.V., 2021. COVID19 and the Global Shift Progress to Clean Energy. J. Energy Resour. Technol. 143, 94701. https://doi.org/10.1115/1.4050779

Ibrahim, A., 2016. Investigating the effect of using diethyl ether as a fuel additive on diesel engine performance and combustion. Appl. Therm. Eng. https://doi.org/10.1016/j.applthermaleng.2016.07.061

Işık, M.Z., Topkaya, H., İşcan, B., Aydın, H., 2020. Combustion, performance, and emissions of safflower biodiesel with dimethyl ether addition in a power generator diesel engine. Energy Sources, Part A Recover. Util. Environ. Eff. 1-16.

Issa, M., Ibrahim, H., Ilinca, A., Hayyani, M.Y., 2019. A review and economic analysis of different emission reduction techniques for marine diesel engines. Open J. Mar. Sci. 9, 148.

Jawre, S.S., Bhagat, A., Moghe, S.M., Pakhale, V.A., 2016. Diethyl ether as additive and its effect on diesel engine performance-a review. Glob. Res. Dev. J. Eng. 1, 27-31.

Joy, N., Yuvarajan, D., Beemkumar, N., 2019. Performance evaluation and emission characteristics of biodieselignition enhancer blends propelled in a research diesel engine. Int. J. Green Energy 16, 277-283.

Kaimal, V.K., Vijayabalan, P., 2016. An investigation on the effects of using DEE additive in a DI diesel engine fuelled with waste plastic oil. Fuel 180, 90-96.

Kapilan, N., Mohanan, P., Reddy, R.P., 2008. Performance and emission studies of diesel engine using diethyl ether as oxygenated fuel additive. SAE Technical Paper.

Keleş, S., 2011. Fossil energy sources, climate change, and alternative solutions. Energy Sources, Part A Recover. Util. Environ. Eff. 33, 1184-1195.

Kerschgens, B., Cai, L., Pitsch, H., Heuser, B., Pischinger, S., 2016. Di-n-buthylether, n-octanol, and n-octane as fuel candidates for diesel engine combustion. Combust. Flame. https://doi.org/10.1016/j.combustflame.2015.09.001

Khalife, E., Tabatabaei, M., Demirbas, A., Aghbashlo, M., 2017. Impacts of additives on performance and emission characteristics of diesel engines during steady state operation. Prog. Energy Combust. Sci. https://doi.org/10.1016/j.pecs.2016.10.001

Khan, M.S., Ahmed, I., Abdul Muta, I. Bin, Bostum, A., 2015. Role of Oxygenated Additives for Diesel Fuel Blend "A Short Review.” J. Appl. Sci. 15, 619-625. https://doi.org/10.3923/jas.2015.619.625

Kim, H.J., Park, S.H., 2016. Optimization study on exhaust emissions and fuel consumption in a dimethyl ether (DME) fueled diesel engine. Fuel 182, 541-549.

Korczewski, Z., 2021. Test Method for Determining the Chemical Emissions of a Marine Diesel Engine Exhaust in Operation. Polish Marit. Res. 28, 76-87.

Kumar, C., Rana, K., Tripathi, B., Gupta, P., 2018. Combustion characteristics of methanol blended diesel fuel in CI engine. Int J Pharm Sci.

Kumar, C., Rana, K.B., Tripathi, B., 2020. Performance evaluation of diesel-additives ternary fuel blends: An experimental investigation, numerical simulation using hybrid Entropy-TOPSIS method and economic analysis.
Therm. Sci. Eng. Prog. 20, 100675.

Labeckas, G., Slavinskas, S., Rudnicki, J., Zadrag, R., 2018. The effect of oxygenated diesel-n-butanol fuel blends on combustion, performance, and exhaust emissions of a turbocharged CRDI diesel engine. Polish Marit. Res. 25, 108-120.

Lautenschütz, L., Oestreich, D., Seidenspinner, P., Arnold, U., Dinjus, E., Sauer, J., 2016. Physico-chemical properties and fuel characteristics of oxymethylene dialkyl ethers. Fuel 173 https://doi.org/10.1016/j.fuel.2016.01.060

Lawan, I., Zhou, W., Garba, Z.N., Zhang, M., Yuan, Z., Chen, L., 2019. Critical insights into the effects of bio-based additives on biodiesels properties. Renew. Sustain. Energy Rev. 102, 83-95. https://doi.org/10.1016/j.rser.2018.12.008

Le, A.T., Hoang, A.T., 2019. A review on deposit formation in the injector of diesel engines running on biodiesel. Energy Sources, Part A Recover. Util. Environ. Eff. 41, 584-599. https://doi.org/10.1080/15567036.2018.1520342

Le Anh, T., Pham Van, V., Anh Hoang, T., 2019. A core correlation of spray characteristics, deposit formation, and combustion of a high-speed diesel engine fueled with Jatropha oil and diesel fuel. Fuel 244, 159-175. https://doi.org/10.1016/j.fuel.2019.02.009

Le, T.H., Huynh, T.T., Nguyen, X.P., Nguyen, T.K.T., 2021. An analysis and review on the global NO2 emission during lockdowns in COVID-19 period. Energy Sources, Part A Recover. Util. Environ. https://doi.org/10.1080/15567036.2021.1902431

Le, V.V., Hoang, A.T., 2017. The Performance of A Diesel Engine Fueled With Diesel Oil, Biodiesel and Preheated Coconut Oil. Int. J. Renew. Energy Dev. 6, 1-7.

Le, V.V., Nižetić, S., Ölçer, A.I., 2021. Flame Characteristics and Ignition Delay Times of 2,5-Dimethylfuran: A Systematic Review With Comparative Analysis. J. Energy Resour. Technol. 143. https://doi.org/10.1115/1.4048673

Leach, F., Kalghatgi, G., Stone, R., Miles, P., 2020. The scope for improving the efficiency and environmental impact of internal combustion engines. Transp. Eng. 1, 100005. https://doi.org/10.1016/j.treng.2020.100005

Lee, S., Kim, T.Y., 2017. Performance and emission characteristics of a DI diesel engine operated with diesel/DEE blended fuel. Appl. Therm. Eng. 121, 454-461.

Lin, C.-Y., Huang, J.-C., 2003. An oxygenating additive for improving the performance and emission characteristics of marine diesel engines. Ocean Eng. 30, 1699-1715.

Maji, S., Ahmed, S., Siddiqui, W.A., Kumar, A., 2014. Impact of Di-Methyl Ether (DME) As an Additive Fuel for Compression Ignition Engine in Reduction of Urban Air Pollution. Int. J. Innov. Res. Sci. Eng. Technol. 03, 1722117228. https://doi.org/10.15680/ijirset.2014.0311020

Minh, T., Anh, T., 2018. Influences of heating temperatures on physical properties, spray characteristics of bio-oils and fuel supply system of a conventional diesel engine. Int. J. Adv. Sci. Eng. Inf. Technol. https://doi.org/10.18517/ijaseit.8.5.5487

Miyamoto, N., Ogawa, H., Nabi, M.N., 2000. Approaches to extremely low emissions and efficient diesel combustion with oxygenated fuels. Int. J. Engine Res. 1, 71-85.

Mohan, B., Yang, W., Yu, W., Tay, K.L., 2017. Numerical analysis of spray characteristics of dimethyl ether and diethyl ether fuel. Appl. Energy 185, 1403-1410.

Mohanan, P., Kapilan, N., Reddy, R.P., 2003. Effect of diethyl ether on the performance and emission of a 4-S Di diesel engine. SAE Technical Paper.

Morales Bayetero, C., Mafla Yépez, C., Benavides Cevallos, I., Hernández Rueda, E., 2021. Effect of the use of additives in biodiesel blends on the performance and opacity of a diesel engine. Mater. Today Proc. https://doi.org/10.1016/j.matpr.2021.07.478

More, G.V., Koli, S.R., Rao, Y.V.H., Prasad, P.I., Rao, B.N., 2020. Effect of compression ratio on compression ignition engine with RUCO biodiesel/ diethyl ether/ diesel fuel blends. 
Energy Sources, Part A Recover. Util. Environ. Eff. 00, 120. https://doi.org/10.1080/15567036.2020.1785593

Mukherjee, A., Bruijnincx, P., Junginger, M., 2020. A Perspective on Biofuels Use and CCS for GHG Mitigation in the Marine Sector. iScience $\quad 23$ 101758. https://doi.org/10.1016/j.isci.2020.101758

Murugesan, P., Perumal Venkatesan, E., Santosh Kumar, D., Balasubramanian, D., Le, A.T., Pham, V.V., 2021. Role of hydrogen in improving performance and emission characteristics of homogeneous charge compression ignition engine fueled with graphite oxide nanoparticleadded microalgae biodiesel/diesel blends. Int. J. Hydrogen Energy. https://doi.org/10.1016/j.ijhydene.2021.08.107

Nayak, S.K., Behera, G.R., Mishra, P.C., Kumar, A., 2017. Functional characteristics of jatropha biodiesel as a promising feedstock for engine application. Energy Sources, Part A Recover. Util. Environ. Eff. 39, 299-305. https://doi.org/10.1080/15567036.2015.1120826

Nayak, S.K., Hoang, A.T., Nayak, B., Mishra, P.C., 2021. Influence of fish oil and waste cooking oil as post mixed binary biodiesel blends on performance improvement and emission reduction in diesel engine. Fuel 289, 119948.

Nayak, S.K., Huynh, T.T., Ölçer, A., Le, A.T., 2020. A remarkable review of the effect of lockdowns during COVID-19 pandemic on global PM emissions. Energy Sources, Part A Recover. Util. Environ. Eff. 1-16. https://doi.org/10.1080/15567036.2020.1853854

Nayak, S.K., Nižetić, S., Nguyen, X.P., Le, T.H., 2022. Effects of advanced injection timing and inducted gaseous fuel on performance, combustion and emission characteristics of a diesel engine operated in dual-fuel mode. Fuel 310, 122232. https://doi.org/10.1016/j.fuel.2021.122232.

Nayaka SK, Nižetić S, Huang Z, et al (2021) Influence of injection timing on performance and combustion characteristics of compression ignition engine working on quaternary blends of diesel fuel, mixed biodiesel, and t-butyl peroxide. J Clean Prod

Nguyen, D.C., Tran, Q.V., Hadiyanto, H., Wattanavichien, K., Pham, V.V., 2020. A review on the performance, combustion and emission characteristics of SI engine fueled with 2,5-Dimethylfuran (DMF) compared to ethanol and gasoline. J. Energy Resour. Technol. https://doi.org/10.1115/1.4048228

Nguyen HP, Hoang AT, Le AT, et al (2020) Learned experiences from the policy and roadmap of advanced countries for the strategic orientation to electric vehicles: A case study in Vietnam. Energy Sources, Part A Recover Util Environ Eff 1-10. https://doi.org/10.1080/15567036.2020.1811432

Nguyen, X.P., Hoang, A.T., 2020. The Flywheel Energy Storage System: An Effective Solution to Accumulate Renewable Energy, in: 2020 6th International Conference on Advanced Computing and Communication Systems, ICACCS 2020. IEEE, Coimbatore, India, India, pp. 13221328. https://doi.org/10.1109/ICACCS48705.2020.9074469

Nižetić, S., Chyuan Ong, H., Tarelko, W., Viet Pham, V., Hieu Le, T., Quang Chau, M., Phuong Nguyen, X., 2021a. A review on application of artificial neural network (ANN) for performance and emission characteristics of diesel engine fueled with biodiesel-based fuels. Sustain. Energy Technol. Assessments 47, 101416. https://doi.org/10.1016/j.seta.2021.101416

Nižetić, S., Le, A.T., Bui, V.G., 2020. Combustion and emission characteristics of spark and compression ignition engine fueled with 2, 5-Dimethylfuran (DMF): A comprehensive review. Fuel 119757.

Nižetić, S., Ng, K.H., Papadopoulos, A.M., Le, A.T., Kumar, S., Hadiyanto, H., 2022. Microbial fuel cells for bioelectricity production from waste as sustainable prospect of future energy sector. Chemosphere 287, 132285. https://doi.org/10.1016/j.chemosphere.2021.132285

Nižetić, S., Pham, V.V., Hoang, A.T., 2021b. A state-of-the-art review on emission characteristics of SI and CI engines fueled with 2,5-dimethylfuran biofuel. Environ. Sci. Pollut. Res. 28, 4918-4950. https://doi.org/10.1007/s11356-020-
$11629-8$

Nižetić, S., Viet Pham, V., Tuan Le, A., Ga Bui, V., Vang Le, V., 2021c. Combustion and emission characteristics of spark and compression ignition engine fueled with 2,5dimethylfuran (DMF): A comprehensive review. Fuel 288, 119757. https://doi.org/10.1016/j.fuel.2020.119757

Noor, M.M., Pham, X.D., Tuan, H.A., 2018. Comparative Analysis on Performance and Emission Characteristic of Diesel Engine Fueled with Heated Coconut Oil and Diesel Fuel. Int. J. Automot. Mech. Eng. 15, 5110-5125. https://doi.org/10.15282/ijame.15.1.2018.16.0395

Ölçer, A.I., Huynh, T.T., Nguyen, X.P., 2021a. Record decline in global $\mathrm{CO} 2$ emissions prompted by COVID-19 pandemic and its implications on future. Energy Sources, Part A Recover. Util. Environ. Eff. https://doi.org/10.1080/15567036.2021.1879969

Ölçer, A.I., Nižetić, S., Hoang, A.T., 2021b. Prospective review on the application of biofuel 2,5-dimethylfuran to diesel engine. J. Energy Inst. 94, 360-386. https://doi.org/10.1016/j.joei.2020.10.004

Ommi, F., Nekofar, K., Pirozfar, V., 2009. Emission and properties characteristics using additive-ethanol-diesel fuel blends on a diesel engine. Ann. Fac. Eng. HunedoraJournal Eng. 7, 35-42.

Ong, H.C., Nižetić, S., Ölçer, A.I., 2020. Synthesis pathway and fundamental combustion mechanism of a sustainable biofuel 2,5-Dimethylfuran: Progress and prospective. Fuel.

Pandey A, Luque R, Ong HC, et al (2021) Characteristics of hydrogen production from steam gasification of plant originated lignocellulosic biomass and its prospects in Vietnam. Int J Hydrogen Energy

Patil, K.R., Thipse, S.S., 2015. Experimental investigation of CI engine combustion, performance and emissions in DEEkerosene-diesel blends of high DEE concentration. Energy Convers. Manag. 89, 396-408.

Paul, A., Bose, P.K., Panua, R., Debroy, D., 2015. Study of performance and emission characteristics of a single cylinder CI engine using diethyl ether and ethanol blends. J. Energy Inst. https://doi.org/10.1016/j.joei.2014.07.001

Pham, V.V., Hoang, A.T., 2019a. Impact of Jatropha Oil on Engine Performance, Emission Characteristics, Deposit Formation, and Lubricating Oil Degradation. Combust. Sci. Technol. 191, 504-519. https://doi.org/10.1080/00102202.2018.1504292

Pham, V.V., Hoang, A.T., 2019b. A study of emission characteristic, deposits, and lubrication oil degradation of a diesel engine running on preheated vegetable oil and diesel oil. Energy Sources, Part A Recover. Util. Environ. Eff. 41, 611-625. https://doi.org/10.1080/15567036.2018.1520344

Pochareddy, Y.K., Ganeshram, A.K., Pyarelal, H.M., Sridharan, S., Asokan, A., Dhamodaran, G., Duraisamy, P., 2017. Performance and emission characteristics of a stationary direct injection compression ignition engine fuelled with diethyl ether-sapote seed oil methyl ester-diesel blends. Biofuels 8, 297-305.

Pranesh, G., Samuel, P.M., Thankachan, B., Manimaran, M., Silambarasan, R., 2015. Performance and emission characteristics of blending diethyl ether in cotton seed oil methyl ester using a direct injection diesel engine. Int. J. Appl. Mech. Prod. Eng. 1, 14-16.

Rakopoulos, D.C., Rakopoulos, C.D., Giakoumis, E.G., Dimaratos, A.M., 2013. Studying combustion and cyclic irregularity of diethyl ether as supplement fuel in diesel engine. Fuel 109, 325-335.

Rakopoulos, D.C., Rakopoulos, C.D., Giakoumis, E.G., Dimaratos, A.M., 2012. Characteristics of performance and emissions in high-speed direct injection diesel engine fueled with diethyl ether/diesel fuel blends. Energy 43, 214-224.

Rao, R., Sharma, A., Nayyar, A., Kumar, C., 2020. Performance and Emission Characteristics of Diesel-2 Ethoxyethyl Acetate-Nitromethane Blends on a CI Engine - An 
Experimental Study. SAE Tech. Pap. https://doi.org/10.4271/2020-01-0347

Ruina, L., Zhong, W., Peiyong, N., Haobin, J., 2021. Effects of exhaust gas recirculation on the particulates structure characteristics of diesel engine fueled with diesel/biodiesel blend. Energy Sources, Part A Recover. Util. Environ. Eff. 43, 3303-3319.

Sadhik Basha, J., 2018. Impact of Carbon Nanotubes and DiEthyl Ether as additives with biodiesel emulsion fuels in a diesel engine - An experimental investigation. J. Energy Inst. 91, 289-303. https://doi.org/10.1016/j.joei.2016.11.006

Sezer, I., 2011. Thermodynamic, performance and emission investigation of a diesel engine running on dimethyl ether and diethyl ether. Int. J. Therm. Sci. 50, 1594-1603.

Sezer, İ., 2020. A review study on using diethyl ether in diesel engines: Effects on fuel properties, injection, and combustion characteristics. Energy Environ. 31, 179-214. https://doi.org/10.1177/0958305X19856751

Sezer, İ., 2019. A Review Study on the Using of Diethyl Ether in Diesel Engines: Effects on CO2 Emissions. J. Chinese Soc. Mech. Eng. Trans. Chinese Inst. Eng. Ser. C/Chung-Kuo Chi Hsueh K. Ch'eng Hsuebo Pao 40, 263-272. https://doi.org/10.31590/ejosat.539318

Sezer, I., 2018. A Review Study on the Using of Diethyl Ether in Diesel Engines: Effects on Fuel Properties and Engine Performance. Energy Technol. 6, 2084-2114. https://doi.org/10.1002/ente.201800158

Shoar, F.H., Najafi, B., Mosavi, A., 2021. Effects of triethylene glycol mono methyl ether (TGME) as a novel oxygenated additive on emission and performance of a dual-fuel diesel engine fueled with natural gas-diesel/biodiesel. Energy Reports 7, 1172-1189.

Sivamurugan, P., Devarajan, Y., 2021. Emission analysis of dual fuelled diesel engine. Int. J. Ambient Energy 42, 15-17.

Sood, R., Kumar, A., Batth, G.S., 2014. Experimental Utilization of 2-Ethoxy Ethyl Acetate as a Blend in a Single Cylinder CI Engine. Int. J. Emerg. Sci. Eng. 2, 21-23.

Srinivasan, P., Devaradjane, G., 2008. Experimental Investigations on Performance and Emission Characteristics of Diesel Fuel Blended with 2-Ethoxy Ethyl Acetate and 2-Butoxy Ethanol. SAE Technical Paper.

Subramanian M, Hoang AT, Kalidasan B, et al (2021) A technical review on composite phase change material based secondary assisted battery thermal management system for electric vehicles. J Clean Prod 129079

Sudeshkumar, M.P., Devaradjane, G., Vincent, V.J., 2012. Experimental analysis of DMM and 2-EEA diesel fuel additives for use in direct injection compression ignition engines. Int J Theo Appl Res Mech Eng 1, 127-131.

Sukjit, E., Herreros, J.M., Dearn, K.D., García-Contreras, R., Tsolakis, A., 2012. The effect of the addition of individual methyl esters on the combustion and emissions of ethanol and butanol -diesel blends. Energy. https://doi.org/10.1016/j.energy.2012.03.041

Tabatabaei, M., Aghbashlo, M., Carlucci, A.P., Ölçer, A.I., Le, A.T., Ghassemi, A., 2021. Rice bran oil-based biodiesel as a promising renewable fuel alternative to petrodiesel: A review. Renew. Sustain. Energy Rev. 135, 110204. https://doi.org/10.1016/j.rser.2020.110204

Tang, C., Guan, L., Feng, Z., Zhan, C., Yang, K., Huang, Z., 2017. Effect of di-n-butyl ether blending with soybean-biodiesel on the near-nozzle spray characteristics. Fuel 191, 300311.

Tham, B.C., Vang, L. Van, Viet, P. Van, 2019. An investigation of deposit formation in the injector, spray characteristics, and performance of a diesel engine fueled with preheated vegetable oil and diesel fuel. Energy Sources, Part A Recover. Util. Environ. Eff. 41, 2882-2894. https://doi.org/10.1080/15567036.2019.1582731

Thambiyapillai, S., Ramanujam, M., 2021. An Experimental Investigation and Aspen HYSYS Simulation of Waste Polystyrene Catalytic Cracking Process for the Gasoline Fuel Production. Int. J. Renew. Energy Dev. 10, 891-900.
Thomas, S., Sandro Nižetić, Olcer, A.I., Ong, H.C., Chen, W.-H., Chong, C.T., Bandh, S.A., Nguyen, X.P., 2021. Impacts of COVID-19 pandemic on the global energy system and the shift progress to renewable energy: Opportunities, challenges, and policy implications. Energy Policy 154, 112322. https://doi.org/10.1016/j.enpol.2021.112322

Thu, N., Anh, H., 2017. Emission characteristics of a diesel engine fuelled with preheated vegetable oil and biodiesel. Philipp. J. Sci 146, 475-482.

Tran, D.Q., Tran, T.T., Le, A.T., 2020. Performance and combustion characteristics of a retrofitted CNG engine under various piston-top shapes and compression ratios. Energy Sources, Part A Recover. Util. Environ. Eff. 1-17. https://doi.org/10.1080/15567036.2020.1804016

Tran, V.D., Dong, V.H., Le, A.T., 2019. An experimental analysis on physical properties and spray characteristics of an ultrasound-assisted emulsion of ultra-low-sulphur diesel and Jatropha-based biodiesel. J. Mar. Eng. Technol. https://doi.org/10.1080/20464177.2019.1595355

Tran, V.D., Le, A.T., Hoang, A.T., 2021. An Experimental Study on the Performance Characteristics of a Diesel Engine Fueled with ULSD-Biodiesel Blends. Int. J. Renew. Energy Dev. 10.

Tree, D.R., Cooley, W.B., 2001. A comparison and model of NOx formation for diesel fuel and diethyl ether, in: SAE Technical Papers. https://doi.org/10.4271/2001-01-0654

Trung, H., Vladimirovich, V.S., Hoang, A.T., 2021. Power generation characteristics of a thermoelectric modulesbased power generator assisted by fishbone-shaped fins: Part I - effects of hot inlet gas parameters. Energy Sources, Part A Recover. Util. Environ. Eff. 43, 588-599. https://doi.org/10.1080/15567036.2019.1630035

Uyaroğlu, A., Gürü, M., Kocakulak, T., Uyumaz, A., Solmaz, H., 2021. Combustion, performance and emission analyses of organic Manganese-Added crambe abyssinica biodiesel in a direct injection diesel engine. Fuel 297, 120770.

Van, P., Anh, H., 2019. Technological perspective for reducing emissions from marine engines. Int. J. Adv. Sci. Eng. Inf. Technol. https://doi.org/10.18517/ijaseit.9.6.10429

Viet Pham, V., Tuan Hoang, A., 2021. 2-Methylfuran (MF) as a potential biofuel: A thorough review on the production pathway from biomass, combustion progress, and application in engines. Renew. Sustain. Energy Rev. 148, 111265. https://doi.org/10.1016/j.rser.2021.111265

Viet, P. Van, Tuan, H.A., 2018. A review on fuels used for marine diesel engines. J. Mech. Eng. Res. Dev. 41, 22-32.

Vinayagam, N.K., Hoang, A.T., Solomon, J.M., Subramaniam, M., Balasubramanian, D., EL-Seesy, A.I., Nguyen, X.P., 2021. Smart control strategy for effective Hydrocarbon and Carbon monoxide emission reduction on a conventional diesel engine using the pooled impact of pre-and postcombustion techniques. J. Clean. Prod. 127310.

Vinh, Q.T., Duong, X.P., Anh, T.H., 2018. Performance and emission characteristics of popular 4-stroke motorcycle engine in vietnam fuelled with biogasoline compared with fossil gasoline. Int. J. Mech. Mechatronics Eng 18, 97-103.

Vo, A.V., Bui, V.G., Tran, V.N., Bui, T.M.T., 2020. A simulation study on a port-injection SI engine fueled with hydroxyenriched biogas. Energy Sources, Part A Recover. Util. Environ. https://doi.org/10.1080/15567036.2020.1804487

Wang, S., Yao, L., 2020. Effect of Engine Speeds and Dimethyl Ether on Methyl Decanoate HCCI Combustion and Emission Characteristics Based on Low-Speed Two-Stroke Diesel Engine. Polish Marit. Res. 27, 85-95. https://doi.org/10.2478/pomr-2020-0030

Wei, H., Yao, C., Pan, W., Han, G., Dou, Z., Wu, T., Liu, M., Wang, B., Gao, J., Chen, C., 2017. Experimental investigations of the effects of pilot injection on combustion and gaseous emission characteristics of diesel/methanol dual fuel engine. Fuel 188, 427-441.

Wu, S., Bao, J., Wang, Z., Zhang, H., Xiao, R., 2021. The regulated emissions and PAH emissions of bio-based long-chain 
ethers in a diesel engine. Fuel Process. Technol. 214, 106724 .

Xuan, N., Van, P., Anh, H., 2021. Use of Biodiesel Fuels in Diesel Engines, in: Biodiesel Fuels. CRC Press, pp. 317-341.

Xuan, P., Viet, P., 2021. Integrating renewable sources into energy system for smart city as a sagacious strategy towards clean and sustainable process. J. Clean. Prod. 305, 127161. https://doi.org/10.1016/j.jclepro.2021.127161

Yan, W., WANG, W., CHEN, Y., ZHENG, J., LI, R., 2013. Synthesis of dimethyl ether from syngas using a hierarchically porous composite zeolite as the methanol dehydration catalyst. J. Fuel Chem. Technol. 41, 873-880.

Yanfeng, G., Shenghua, L., Hejun, G., Tiegang, H., Longbao, Z., 2007. A new diesel oxygenate additive and its effects on engine combustion and emissions. Appl. Therm. Eng. https://doi.org/10.1016/j.applthermaleng.2006.04.021

Yanxia, W., Yongqi, L., 2007. Diesel engine emission improvements by the use of EGM-DMC-Diesel blends fuel, in: 5th WSEAS Int. Conf. on Environment, Ecosystems and Development, Tenerife, Spain. Citeseer, pp. 14-16.

Yesilyurt, M.K., Aydin, M., 2020. Experimental investigation on the performance, combustion and exhaust emission characteristics of a compression-ignition engine fueled with cottonseed oil biodiesel/diethyl ether/diesel fuel blends. Energy Convers. Manag. 205, 112355. https://doi.org/10.1016/j.enconman.2019.112355
Yetri, Y., Mursida, Dahlan, D., Muldarisnur, Taer, E., Chau, M.Q., 2020. Synthesis of activated carbon monolith derived from cocoa pods for supercapacitor electrodes application. Energy Sources, Part A Recover. Util. Environ. Eff. 1-15. https://doi.org/10.1080/15567036.2020.1811433

Yondri, S., Nguyen, X.P., Le, A.T., Pham, M.T., Hoang, T.H., AlTawaha, A.R.M.S., 2021. Power generation characteristics of a thermoelectric modules-based power generator assisted by fishbone-shaped fins: Part II - Effects of cooling water parameters. Energy Sources, Part A Recover. Util. Environ. $\quad$ Eff. 381-393. https://doi.org/10.1080/15567036.2019.1624891

Zeńczak, W., Krystosik-Gromadzińska, A., 2020. Preliminary analysis of the use of solid biofuels in a ship's power system. Polish Marit. Res. 4, 67-79.

Zhao, Y., Wang, Y., Li, D., Lei, X., Liu, S., 2014. Combustion and emission characteristics of a DME (dimethyl ether)-diesel dual fuel premixed charge compression ignition engine with EGR (exhaust gas recirculation). Energy 72, 608-617.

Zhu, Q., Zong, Y., Yu, W., Yang, W., Kraft, M., 2021. Understanding the blending effect of polyoxymethylene dimethyl ethers as additive in a common-rail diesel engine. Appl. Energy 300, 117380. 